\title{
Alignment and Word Order in Old Japanese
}

Yuko Yanagida (University of Tsukuba)

John Whitman (Cornell University)

\section{Introduction}

This paper discusses the syntactic alignment of the two major clause types in Old Japanese (OJ, $8^{\text {th }}$ century): conclusive (1) and what we label 'nominalized' clauses, represented by the adnominal examples in (2). ${ }^{1}$

Conclusive:

(1)
見度波
安麻乎等女登母
多麻藻可流美由
Mi-watas-eba amawotomye-domo
tamamo karu miy-u.
(MY 17/3890)
look-cross-when fisher maiden-Pl seaweed gather appear-Conc
'When (I) surveyed the scene, the fishermaidens appeared to be gathering seaweed.'

Nominalized (adnominal):

（2） a. 佐欲比売能故何比列布利斯夜麻

(MY 5/868)

Saywopimye no kwo ga pire puri-si yama

SayohimeGen child Agt scarf wave-Pst.Adn mountain

'the mountain where Sayohime waved her cloth'

b. 和藝毛古我 蘇弓母志保保尔 奈伎志曾母波由

(MY 20/4357)

Wagimokwo ga swode mo sipopo ni naki-si so [o]mopayu.

my.wife Agt sleeves even drenched cry-Pst.Adn Foc long.for

'I long for my wife, who cries so that even her sleeves were sopping.'

c. 久木生留清河原尔

pisakwi Ø opu-ru kiywoki kapara $n i$

(MY 6/925)

catalpa grow-Adn clear riverbank on

'on the banks of the clear river where catalpas grow'

We argue that while conclusive clauses display nominative-accusative alignment, nominalized clauses have active alignment. In active languages, also known as active-stative (Klimov 1974, 1977; Mithun 1991), the sole argument of an intransitive verb shows two distinct patterns: generally speaking, agentive intransitive subjects pattern with transitive subjects; non-agentive ones pattern with transitive objects. We see such a pattern in (2). In 
(2a-b) the external argument, that is, the agent of the transitive (2a) and unergative (2b) verbs, is marked by the particle $g a$. In (2c), the patient subject of the unaccusative verb behaves like the object of the transitive verb in (2a): both are morphologically bare and occur immediately adjacent to the verb.

Other nominalized clause types include clauses inflected in the realis (izenkei) (3a), irrealis (mizenkei) conditionals (3b), and nominal clauses in $-(a) k u(3 \mathrm{c})$.

\section{(3) a. Realis (izenkei) conditional \\ 和賀己藝由氣婆 \\ wa ga kogi yuke-e-ba}

(MY 14/3993)

I Agt row go-Rls-when

'when I went rowing.'

b. Irrealis (mizenkei) conditional

真幸而伊毛我伊波伴伐

masakikute imo ga ipap-a-ba

(MY 15/3583)

safely wife Agt bless-Irs-if

'if you bless me godspeed'

c. V-aku Nominal form ${ }^{2}$

乎登賣良我伊米尔都具良久

wotome-raga ime ni tug-uraku

(MY 16/4011)

maiden-Pl Agt dream in recount-Noml

'what the maidens recounted in my dream'

Each of the nominalized clause types in (3) share the active alignment properties of adnominal clauses in (2), beginning with marking of the external argument by $g a$.

Transitive nominalized clauses display another important property. As described in detail by Yanagida (2006), when the direct object is marked with accusative wo, it precedes the $g a$-marked external argument in nominalized clauses, as shown in (4):

(4) 花 橘 乎

\section{譏嬬良我珠貫麻泥尔}

pana tatibana wo wotomye-raga tama nuku made ni (MY 19/4166)

orange blossom Obj maiden-s Agt bead thread-Adn until

'until the maidens thread the orange blossoms on their beads'

We develop an analysis of OJ nominalized clauses that accounts for the co-occurrence of the active alignment properties in (2) and the [O wo S ga V] object marking pattern in 4. Nominalized clauses assign inherent case, spelled out as $g a$, to the external argument in its base position in Spec, $v$ P. Following a proposal due to Miyagawa (1989), nominalized verbal projections fail to assign accusative case. Two case licensing strategies are available for 
direct objects: they may be assigned case, spelled out as wo, in the specifier of a functional projection above $v \mathrm{P}$, as in (4); or, if they are non-branching, they may undergo incorporation into the verb (Yanagida 2005, 2007a, b). The second strategy is also available for patient subjects, as is wo marking in a limited context first pointed out by Vovin (1997) and described in section 5 .

The paper is organized as follows. Section 2 reviews previous analyses. Section 3 outlines the typological properties of active alignment, emphasizing that it has important differences from the better known ergative pattern. Section 4 shows that nominalized clauses in OJ share active alignment properties in two specific domains: case marking of subject arguments, prefixal crossreferencing of the subject argument on the verb. This section presents a formal analysis of active alignment in OJ. Section 5 focuses on object marking in nominalized clauses. In section 6 we discuss the diachronic sources of the OJ alignment pattern in a broader typological context. Section 7 concludes the paper.

\section{Previous Analyses}

\subsection{Miyagawa (1989) and Miyagawa and Ekida (2003)}

Miyagawa (1989) proposes that in OJ and Early Middle Japanese, adnominal and conclusive clauses have distinct case assigning mechanisms. The conclusive form of the verb is truly verbal and assigns abstract case to the object in underlying object position, while the adnominal form has nominal properties and has no case assigning ability. In adnominal clauses, the object is assigned overt structural case in the form of wo in order to avoid a violation of the Case Filter. Miyagawa's (1989) generalization is stated in (3).

(5) Miyagawa's (1989) generalization (1989: 206)

Accusative Case Assignment: The conclusive form assigns abstract case while the case assigning feature of the attributive (=adnominal) form must be manifested overtly as wo.

Given that overt object case marking is normally required in modern Japanese, Miyagawa (1989) and Miyagawa and Ekida (2003) propose that Japanese underwent a change from an abstract to a morphological case marking language, and that the driving force for this change is the increased use of the adnominal in main clauses. In OJ, nominalized forms including the adnominal are generally restricted to embedded environments (this is exclusively the case for irrealis conditionals and the $-a k u$ nominalized form); the matrix use of the adnominal is predominantly limited to the kakarimusubi focus construction (see Whitman 1997 and references there). The kakarimusubi construction, however, began to break down in EMJ (cf. 
Hendriks 1998), with the result that adnominal inflection came to be used in main clauses without a kakari focus particle and eventually replaced the conclusive in main clauses. Miyagawa (1989) and Miyagawa and Ekida (2003), based on an extensive survey of EMJ literary texts, argue that the reanalysis of adnominal as a main clause predicate form led to the increased use of object marking with wo.

\subsection{Kuroda (2007)}

Kuroda (2007) proposes that the diachronic difference between modern and earlier Japanese is accounted for by an Agreement Parameter (cf. Kuroda 1988): agreement is forced in earlier Japanese, but not in the modern language. In a forced agreement language, movement is triggered by agreement inducing features, and optionality does not come into play. Kuroda proposes that earlier Japanese was a forced agreement language; he claims that wh/focus movement is obligatory, and both subject and object take obligatory abstract case marking. In modern Japanese, in contrast, wh-phrases do not move, relative clause heads need not raise, and abstract case marking is optional. We will show that the alignment characteristics of OJ are compatible with the view that certain, but not all types of movement are forced in OJ nominalized clauses. In particular, complements marked by wo obligatorily move out of VP. However this obligatory movement, together with wh movement in OJ, is associated with the active alignment domain of OJ syntax: nominalized clauses. The characteristic word order flexibility and other types of optionality are allowed in conclusive clauses, the accusative alignment domain.

\subsection{Previous Non-Accusative Analyses of Old Japanese}

\subsubsection{Vovin (1997)}

Vovin (1997) suggests that the suffix $-i$, analyzed as a subject case marker by traditional grammarians, represents in fact active case, marking subjects of transitive and of active intransitive verbs, but not subjects of non-active intransitive verbs. ${ }^{3}$ Vovin further argues that the case marker wo marks absolutive case, in that wo appears not only with the object of transitive verbs, but with the subject of stative predicates, in particular predicates suffixed with $-m i$, called by Vovin "quality stative verbs." Based on the distribution of $-i$ and wo, Vovin concludes that $\mathrm{OJ}$ is a language with active alignment. Although our analysis of OJ active alignment paper differs in many respects from his, Vovin deserves primacy of place as the originator of the hypothesis that OJ syntactic alignment is in important respects non-accusative. 


\subsubsection{Yanagida $(2005,2007 \mathrm{a}, \mathrm{b})$}

Yanagida $(2005,2007 \mathrm{a}, \mathrm{b})$ proposes that the historical change described by Miyagawa (1989) and Miyagawa and Ekida (2003) instantiates the cross-linguistically well-documented change from split ergative to accusative. Yanagida's basic claim is that Old Japanese is an ergative-active language with a split case system; the split occurs between main and embedded clauses, a type identified by Dixon (1994:101-4). Main predicates in the conclusive (shûshikei) form show accusative alignment. Predicates in the non-conclusive forms, i.e. irrealis (mizenkei) conditionals, continuative (renyôkei), adnominal (rentaikei), and realis (izenkei) show ergative-active alignment. Yanagida (2007a) proposes that the adnominal form was a vestigial antipassive, and wo was an oblique case marking the demoted object of the antipassive, but was reanalyzed as an accusative case, when the antipassive was lost in Old Japanese. ${ }^{4}$ A main objective of Yanagida (2007a) is to explain certain apparent counterexamples to Miyagawa's (1989) generalization (5). Yanagida (2007b) shows that in the Man'yôsh $\hat{u}$, there are 90 tokens of transitive clauses whose subject is marked by no or $g a$ but whose object is morphologically unmarked. 55 occur with adnominal predicates, as in (2a), repeated as (6) below.

（6）佐欲比賣能故何 比列布利斯 夜麻

Saywopimye no kwo ga pire puri-si yama

(MY 5/868)

Sayohime Gen child Act scarf wave-PAdn hill Gen

'the name of the hill where Sayohime waved her scarf'

Examples like this are apparent counterexamples to Miyagawa's generalization. However, Yanagida shows that while bare objects do occur with adnominal predicates, there is a clear pattern to the counterexamples: the bare objects are almost without exception non-branching $\mathrm{N}^{0}$ s. Based on these distributional facts, Yanagida proposes that bare objects in nominalized clauses like (6) are incorporated, on the model of languages like Chukchee (Spenser 1999). Chukchee has two types of derived intransitive constructions: a morphologically marked antipassive, and the object incorporation strategy. Yanagida argues that OJ used object incorporation in a similar way. Following the basic approach of Baker (1988), non-branching nouns immediately adjacent to an adnominal predicate are incorporated into the verb, and incorporation satisfies the case requiremens of the incorporee. This preserves Miyagawa's generalization that the object of the adnominal predicate is not assigned abstract case in its base position. ${ }^{5}$ Note importantly that object incorporation is a salient feature of languages with active alignment as observed by Klimov (1977: 125-6; cf. also Sapir 1911). 
In this paper, we retain Yanagida's (2007a, b) analysis of OJ as a language involving split alignment, and in particular her incorporation analysis of examples like (6). The incorporation analysis is dicussed in section 4 . However we do not retain the hypothesis that the adnominal suffix is a vestigial antipassive, for the following reasons.

First, the function of antipassive in ergative languages is to make the clause [-transitive], resulting in assignment of absolutive case to the external argument. But adnominal marking does not have this effect in OJ: the external argument in transitive adnominal clauses is marked with ergative (active) case ( $g a$ ), not absolutive. Second, if adnominal marking in relative clauses was a kind of antipassive, we would expect it to be associated only with subject relatives. This is because of the so-called Absolutive Restriction on A-Bar extraction (Aldridge 2004), which allows only absolutive arguments to undergo relativization (recall that the transitive subject becomes absolutive in antipassives). But the OJ adnominal is used to form relatives of all types ( $\mathrm{cf}(2 \mathrm{a})$, an adjunct relative). Crucially, the adnominal is also used to derive object relatives:

$$
\begin{aligned}
& \text { 垂乳根之 母我養虫 } \\
& \text { [taratine no papa } g a \text { kap-u] kwo } \\
& \text { Mk Gen mother Act breed-Adn silkworm } \\
& \text { 'the silkworms bred by my mother' } \\
& \text { (MY 12/2991) }
\end{aligned}
$$

This is unexpected if the adnominal was an antipassive morpheme.

The third problem with the antipassive hypothesis is morphological. Any arguments for analyzing the adnominal as a vestigial antipassive holds for the other nominalized clauses types as well, since they all occur with $g a$-marked agentive subjects and wo-marked objects in the order OSV. But each of these clause types involves a completely different affix: realis -e-/-ure-, irrealis conditional - $a-$, nominal - $a k u$. This means that there would be no specific morpheme marking the antipassive. The final problem is semantic. In ergative languages, the object argument in antipassives (if realized at all) is typically indefinite or non-referential (Dixon 1994: 148). But wo-marked objects in OJ are typically definite (Motohashi 1989). Again, this fact is unexpected if wo originated as the oblique case marker for objects in antipassives.

In fact, the expectation that an active language should have an antipassive is a product of the view that active is a subtype of ergative alignment. This view has been pervasive in the typological literature since at least Dixon (1979: 80-85), but it is by no means the only view. Other typologists, in particular, Klimov (1974, 1977: 29-43) have claimed that the two alignment types are distinct (see also Wichmann 2008 and the papers collected in Wichmann and Donohue 2008). We argue in the next section, on empirical and formal grounds, that the 
latter view is correct. In particular, the feature [ \pm transitive], which plays a crucial role in the assignment of ergative case and in the derivation of the antipassive in ergative languages, does not play this role in active languages.

In the following section, we outline the typological and formal properties of active alignment, before going on to show how these properties apply to OJ.

\section{Active Alignment}

In Dixon's (1979) basic terminology, S refers to the subject of an intransitive verb, A to the subject of a transitive verb and $\mathrm{O}$ to the object of a transitive verb.

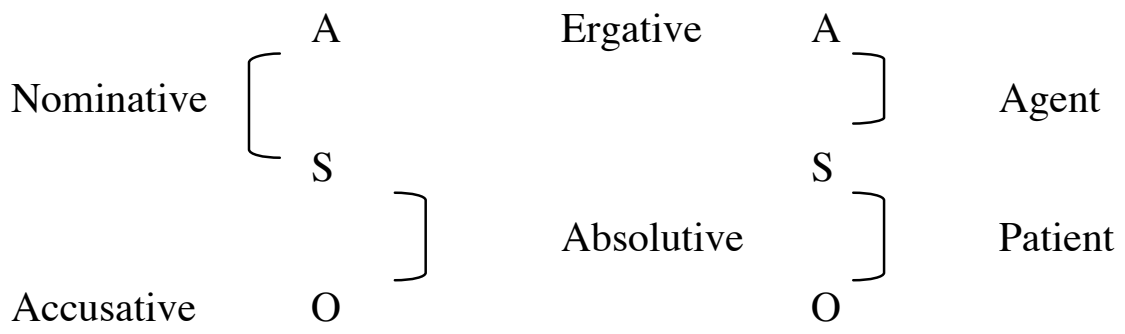

In nominative/accusative languages, $\mathrm{A}$ and $\mathrm{S}$ receive the same case marking (nominative), while $\mathrm{O}$ is distinct (accusative). In ergative/absolutive languages, $\mathrm{S}$ and $\mathrm{O}$ receive the same marking (absolutive), while $\mathrm{A}$ is distinct (ergative). In languages with active alignment, the morphological encoding of intransitive subjects depends on the semantic properties of predicates and their arguments. ${ }^{6}$ Certain intransitive subjects pattern with A, that is, with transitive subjects, while others pattern with objects. Dixon (1979: 80) distinguishes these as $\mathrm{S}_{\mathrm{A}}$ and $\mathrm{S}_{\mathrm{O}}$.

\subsection{Split Intransitivity}

Active languages divide intransitive verbs into active and inactive. The exact lexical division differs crosslinguistically, but the two classes of intransitive verbs are distinguished by case marking: active intransitive subjects $\left(\mathrm{S}_{\mathrm{A}}\right.$, typically the agent argument of unergatives) have the same marking as transitive subjects, whereas inactive intransitive subjects $\left(\mathrm{S}_{\mathrm{O}}\right.$, typically the patient argument of unaccusatives) have the same marking as transitive objects. In Hindi, for example, verbs in perfective aspect show an active pattern: the case marker -ne appears on the subject of transitives and unergatives, but not on the subject of unaccusatives:

(9) Hindi (Mahajan 1990)

a. Raam-ne kelaa khaayaa.

Ram-Erg banana ate 
'Ram ate a banana.'

b. Kutte (ne) bhONke.

dogs (Erg) barked

'The dogs barked.'

c. Siitaa $(* n e)$ aayii.

Sita $(* \operatorname{Erg})$ arrived

'Sita arrived.'

Lotha (Tibeto-Burman) also shows active alignment (Dahlstrom 1983); the case maker -na marks $\mathrm{S}_{\mathrm{A}},-\operatorname{co} \mathrm{S}_{\mathrm{O}}$.

(10) Lotha (Dahlstrom 1983)

a. John-na firo ci echo cho.

John-Subj dog Det hit Perf

'John hit the dog.'

b. Mpo-na oki na hapoi ci yi cho.

he-Subj house from outside Det go Perf

'He went outside (from the house),'

c. Nkolo co a wopan ciag-co Wokka-e van cho.

long ago I family Det-Subj Wokka-Loc live Perf

'Long ago my family lived in Wokka.'

Active alignment can be manifested in the morphological case marked on nouns, as we have seen, but many active languages are strictly head marking: they mark agreement with NP arguments on the verb. Thus in Guraraní $a$ - cross-references $\mathrm{S}_{\mathrm{A}}$; se-cross-references $\mathrm{S}_{\mathrm{O}}$ :

Guaraní (Mithun 1991)

(11) A-xá. 'I go.'

Se-rasí. 'I am sick.'

A-puá. 'I got up.'

Se-ropehií. 'I am sleepy.'

A-gwerú aína. 'I am bringing them now.'

\subsection{The Nominal Hierarchy}

We noted in section 2 that the typological literature has tended to classify active as as a subtype of ergative alignment. One argument against this view is that active languages differ crucially from ergative languages with respect to how ergative splits interact with

Silverstein's (1976) nominal hierarchy:

(12) The Nominal Hierarchy (Silverstein 1976)

$$
\begin{array}{ll}
\text { pronouns }>\text { proper nouns }> & \text { common nouns } \\
1^{\text {st }}>2^{\text {nd }}>3^{\text {rd }} \text { person } & \text { human }>\text { animate }>\text { inanimate }
\end{array}
$$


Dixon (1979) emphasizes that languages termed ergative invariably show splits, that is, nominative/accusative features in certain contexts. This interacts with the nominal hierarchy. Dixon (1979:86-87) interprets the hierarchy to "roughly indicate the overall 'agency potential' of any given NP," and observes that "a number of languages have 'split' case marking exactly on this principle: an 'ergative' case is used with NPs from the right-hand end up to some point in the middle of the hierarchy and an 'accusative' case from that point on, over to the extreme left of the hierarchy." This is exemplified by Thulung Rai (TibetoBurman), an ergative language. The suffix $-k a$ marks A when when it is lower on the hierarchy (Allen 1975, cited by Lahaussois 2003).

(13) Thulung Rai (Lahaussois 2003)

a. Gui pe-pa hal s.l-mu basi.

$1 \mathrm{pl}$ eat-Npst.Prt dish wash-Nom.inf Obl

'We must wash the dishes.'

b. Gatsi mam-lai kr.m-.a 1.-mu basi.

$2 \mathrm{~d}$ mother-Dat visit-Purp go-Nom.Inf Obl

'You two must go visit mother.'

c. Gumimim-ka kam be-mri.

3p-Erg work do-3p/3s.Pst

'They do work.'

d. I-lwak-ka i-mam-lai khl.i.

2Poss-y.sibling-Erg 2Poss-mother-Dat help.3s/3s

'Your younger sibling helps your mother.'

In Thulung Rai, first and second person A appears with nominative case, while third person and common NP A follows an ergative pattern.

A split between pronouns and nouns is also typical of languages with active alignment, but crucially, the nominal hierarchy applies to the argument NPs in the opposite direction, as first suggested by Dahlstrom (1983). First and second person, which are at the top of the hierarchy, show active marking, while common NPs are less likely to be marked.

(14) Lakhota (Dahlstrom 1983)
a. Wa-lowa.
1sg.Ag-sing
'I sing.'
b. Ma-haska.
1sg.Pat-be tall
'I am tall.'
c. Ma-ya-gnaya-pi.
'You pl. tricked me.'
1sg.Pat-2Ag-trick-P1


(15) a. Lowa-pi. sing-Pl

b. Haska-pi. be tall-Pl

c. Ma-gnaya-pi. 1sg.Pat-trick-P1

d. Wicha-wa-gnaya. anim.3Pl.Acc -1sgAG -trick
'They sing.'

'They(anim.) are tall.'

'They tricked me.'

'I tricked them.'

In Lakhota, the first and second person pronouns $w a$ and $m a$ display an active pattern, but third person plural $p i$ has a nominative-accusative distribution. Independent NPs appear neither with morphological cases nor adpositions. As Mithun (1991) points out, case systems based on agency are frequently restricted to nominals referring to human beings. ${ }^{7}$ Thus Koasati shows agentive case marking on pronominal prefixes within verbs but accusative case marking on nouns. The active system in Batsbi (Tsova-Tush) is limited to first and second persons. Central Pomo has an active system in nominals referring to humans only. The Georgian active system is restricted to human beings. The Yuki system is restricted to animates. From these cross-linguistic observations, the implication follows that active marking is used with NPs from the left-hand side to the right-hand side of the nominal hierarchy; that is, if a language has agent marking in third person, it also has agent marking in first and second person. This is exactly the opposite of the right-to-left application of the hierarchy proposed by Dixon for ergative languages. The relationship between active marking and the nominal hierachy is stated in (16):

\section{(16) The Active Marking Hierarchy}

In active languages, if active marking applies to an NP type $\alpha$, it applies to every NP type to the left of $\alpha$ on the nominal hierarchy.

The preceding discussion shows that assignment of active case is dependent not just on the thematic role assigned by the verb, but on the place of $\mathrm{S}$ on the nominal hierarchy. Klimov $(1974,1979)$ emphasizes this point, stressing that in active languages both the semantics of the predicate and the subject NP govern the distribution of active case.

Dixon (1979: 80-83) divides active languages into two groups; "split $S$ " languages such as Tupí-Guaraní and "fluid S" langauges such as Batsbi. In split-S systems, the two classes of intransitive verbs have fixed membership and whether they belong to the active or inactive class is based on their prototypical meaning. In fluid S systems, verbs are divided depending on the meaning of each particular token. The active pattern appears when the $\mathrm{S}$ argument has 
control over the activity and the inactive pattern appears when control is lacking. Consider Batsbi, a fluid S language cited by Comrie (1978:366).

(17) Batsbi: Northeast Caucasian

a. Txo naizdrax qitra. we-Abs. to-the ground fell 'We fell to the ground (unintentionally).'

b. Atxo naizdrax qitra. we-Erg to-the ground fell 'We fell to the ground (intentionally).'

In (17a) the activity is unintentional and the subject is marked absolutive, while in (18b) the activity involves intention, and the subject is marked ergative/active.

Summarizing, the distribution of active of $\mathrm{S}_{\mathrm{A}}$ marking can vary along three dimensions: the prototypical meaning of the verb (whether it is agentive or non-agentive), the degree of control associated with the $\mathrm{S}$ argument, and the place of $\mathrm{S}$ on the nominal hierarchy. Legate (2008) provides a framework that can capture these properties and distinguish active from ergative systems. In Legate's framework, the external argument in ergative languages receives inherent ergative case in its underlying position in the specifier of [+transitive] $v$ Ps. (The analysis of ergative as inherent case assigned to the external argument in situ originates with Woolford (1997) and is shared by such researchers as Aldridge (2004)). In active languages, transitivity plays no role: inherent Active case is assigned to the external argument in Spec, $\mathrm{vP}$ regardless of whether or not $v$ is [+transitive]. We propose that other features may also play a role in the assignment of inherent active case, including person features and semantic features such as [ \pm animate]. This allows us to account for languages where NP type determines the distribution of active case.

\section{Evidence for Active Alignment in Old Japanese}

In this section, we present evidence for active alignment in Old Japanese nominalized clauses, focusing on subject case marking and verbal prefixation.

\subsection{Agent Marking with $g a$}

In modern Tokyo Japanese, $g a$ is clearly a nominative case marker, because it marks both the external argument of transitives and the internal argument of intransitives, as in (18).

(18) a. Taroo ga naita

Taroo Nom cried

'Taroo cried.' 
b. Hana ga saita

flower Nom bloomed

'Flowers bloomed.'

c. Taroo ga hon o katta

Taroo Nom book Acc bought

'Taroo bought a book.'

The distribution of $g a$ in OJ differs significantly from present-day Japanese. $G a$ in OJ is one of two genitive markers; the other is no, which retains this status in modern Japanese. In addition to marking possessors of NP inside DP, both $g a$ and no also mark the subjects of nominalized clauses. $G a$ is restricted to personal nouns whose referent is someone close to the speaker such as imo 'sister, wife, lover', or a pronoun with a specific human referent. No, on the other hand, is used with nonspecific animate nouns, such as pito 'other people', and with inanimate nouns. ${ }^{8}$ The use of $g a$ depends not only on the semantics of the DP it marks but also on the semantics of the predicate. In nominalized clauses, $g a$ is used with active intransitives and transitives (19), while no is used with inactive intransitives (20). ${ }^{9}, 10$

(19) a. 比等豆麻古呂乎伊吉尔和我須流

Pito-dumakoro wo ikini waga suru.

(MY 14/3539)

person wife Obj long for I.Act do-Adn

'I long for another person's wife.'

b. 君我由久道

kimi ga $y u k-u$ miti

(MY 15/3724)

lord Act go-Adn road

'the road that my lord travels'

c. 佐欲比賣能故何比列布利斯夜麻...

Saywopimye no kwoga pire puri-si yama

(MY 5/868)

Sayohime Gen child Act scarf wave-Pst.Adn mountain

'the mountain where Sayohime waved her scarf'

（20） a. 淑人乃 良跡吉見而好常言師芳野

yoki pito no yosi to yoku mite yosi to ipisi Yosino

(MY 1/27)

good people Gen good Comp well looking good Comp say-Pst.Adn Yoshino

'Yoshino, which good people took a good look at and called good, said was good'

b. 花 能 佐久都奇

pana no saku tukwi

(MY 18/4066)

flower Gen bloom month

'the month when flowers are in bloom' 
The first and second pronouns $w a$ and $n a$ are weak pronominal counterparts of the strong pronouns ware and nare respectively. These weak pronouns have the properties of clitics: they are invariably marked with $g a$ and appear strictly adjacent to the verb. ${ }^{11}$ This contrasts with full NP subjects marked by $g a$, which allow an adverb or even a clause to freely appear between the subject and the verb, as shown in (21).

(21) a. 乎登賣良我伊米尔都具良久 wotomye-ra ga ime ni tugur-aku (MY 17/4011) maiden-Pl Act dream-in tell-Nomnl 'The maidens told me in a dream.'

$\begin{array}{lll}\text { b. 和藝毛故我 } & \text { 麻多牟等伊比之 } & \text { 等伎 } \\ \text { wagimokwo ga } & \text { mat-amu to ipi-si } & \text { toki } \\ \text { my.wife Act } & \text { wait-will Comp say-Pst.Adn } & \text { time }\end{array}$
'when my wife said that she would wait'

Given the strict adjacency condition, we assume that the weak pronominals are clitics adjoined directly to the verb.

We see from the semantic differences between $g a$ and no that ga marks NPs higher on the nominal hierarchy in (12), whereas no is used with NPs located lower on the hierarchy. This generalization applies both to $g a$ and no as possessors of NP and markers of subjects (A and S) in nominalized clauses. Note that syncretism between genitive and agentive case is common in non-accusative languages. For clarity, we gloss $g a$ as Act(ive) when it marks the $\mathrm{S}_{\mathrm{A}}$ of a nominalized clause, Gen(itive) when it marks the possessor in DP. No is glossed Gen(itive) throughout.

Now consider the OJ examples below:

$$
\begin{aligned}
& \text { a. 君我由久 道乃奈我弓 } \\
& \text { Kimi ga yuk-u miti no nagate } \\
& \text { Lord Act go-And road Gen length } \\
& \text { 'the length of the road my lord travels' } \\
& \text { b. 明日香河 逝湍乎早見 }
\end{aligned}
$$$$
\text { Asuka-gapa } \varnothing \text { yuk-u se wo paya-mi }
$$

Asuka river go-Adn shallows Obj fast-Mi

'since the shallows where the Asuka River flows are fast'

In (22a), the subject of the predicate $y u k u$ means 'go.' Its subject is human and volitional, and marked with ga. In (22b) yuku means 'flow.' Its inanimate subject Asuka-gapa 'Asuka river' is morphologically unmarked. The choice of subject marking depends on whether the event 
denoted by the verb involves control or intention: only the human participant exercises control. Thus OJ nominal clauses are a fluid-S system, in Dixon's sense described in 3.1.

\subsection{Ga/no Marking and Nominalized Clause Types}

Subjects marked with $g a$ and no appear in the clause types we have characterized as nominalized: adnominal (rentaikei), realis (izenkei), irrealis (mizenkei) conditionals, and -aku nominalizations, but they never appear with predicates in the conclusive form. ${ }^{12}$ Let us look more closely at the evidence that these clause types have nominalized status synchronically at the OJ period. First, as described above, their subjects appear with the genitive case particles $g a$ and no. The semantic distribution of $g a$ and no in marking the possessor in DPs is parallel to their distribution in nominalized clauses: possessors lower on the nominal hierarchy appear with no, while NPs higher on the hierarchy, such as personal pronouns, appear with ga:

(23) a. 楢乃京師乃佐保川

Nara no miyakwo no Sapo kawa

(MY 1/79)

Nara Gen capital Gen Saho river

'the river Sahokawa in Nara.'

b. 和可由都流

伊毛我多毛等

wakayu tur-u imo ga tamoto

(MY 5/857)

young.sweetfish angle-Adn girl Gen wrist

'the arms of my girl who fishes for young sweetfish'

Second, the four clause types appear in positions typical of nominalized clauses:

embedded complement and modifier positions and focus constructions, including questions.

Whitman (1997) shows that it is common, particularly in East and Southeast Asia, for focus and interrogative patterns to be realized with nominalizing morphology on the predicate.

Adnominal clauses appear as focus and interrogative questions, as the object of a postposition or as the subject of a clause. Realis clauses appear as questions, as focus constructions with the particle koso, and as presupposed conditionals typically followed by the particles $-b a$ 'as/since' and -do 'even (though)'. Irrealis conditionals appear with the same two particles. Nominalized - $a k u$ clauses are analyzed as nominalizations by Wrona (2008) and typically occur in complement position. All of the environments above are embedded, all complements of a verb or particle or modifier of NP, except for the focus and question constructions associated with the adnominal and realis.

In this paper we adopt the view that nominalization involves a [nominal] feature associated with the lexical verb and percolated to $\mathrm{T}$, the head of the extended verbal projection. ${ }^{13}$ The fact that the domain of nominalization in OJ is TP is shown by the ability of 
the adnominal, realis, and irrealis conditional endings to select tense, negation, and modals such as presumptive - $m u$. In (2a-b), (20a), and (21), for instance, we see examples of the adnominal form of the past tense auxiliary, spelled out as -si. The 'high' locus of nominalization in OJ resembles languages like Turkish (Kornfilt 2003), where nominalization is at the clausal level. ${ }^{14}$ The concrete representation we propose for OJ nominalized clauses with ga-marked subjects is given in (24), corresponding to (21b).

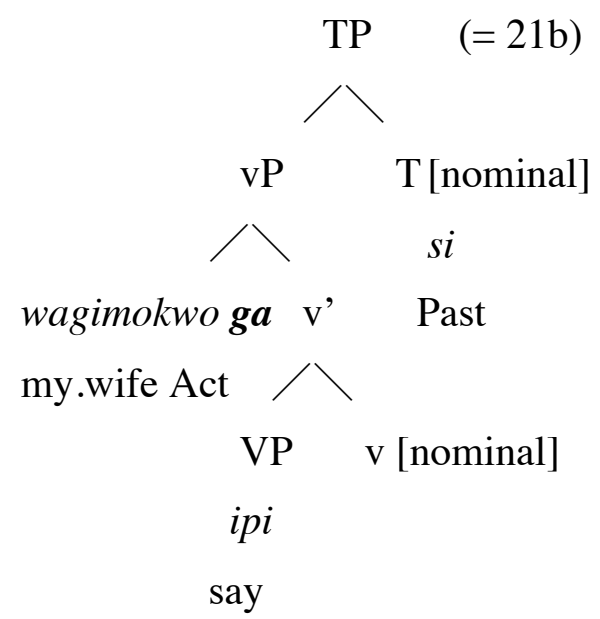

[Nominal] $v$ assigns inherent active case (spelled out as $g a$ ) to external arguments in its specifier. $G a$ thus appears on the subjects of transitives and unergatives, as described in 4.1. In addition, inherent $g a$ is subject to additional featural restrictions typical of active languages as discussed in 3.2, such as the restriction that the active-marked DP be [animate]. In contrast, genitive no is a structural case, assigned by D in DPs such as (23a). We assume that $\mathrm{D}$ is also responsible for assigning no to the subjects of nominalized clauses such as those in (20), much as in modern Japanese (see Miyagawa (1993) for an analysis of D as the licenser of no-marked genitive subjects in modern Japanese). The mechanism of subject no-marking is discussed in greater detail in section 4.4 .

In this section we have described a dependent marking pattern in OJ characeristic of active alignment: $g a$ marking of $\mathrm{A}$ and $\mathrm{S}_{\mathrm{A}}$ in nominalized clauses. In the next section we show that $\mathrm{OJ}$ also displayed head marking patterns characteristic of active alignment.

\subsection{Active/Inactive Prefixes}

A heretofore completely unnoticed piece of evidence for the active alignment of OJ comes from the verbal prefixes $i$ - and $s a$-. Japanese traditional linguists have failed to identify a consistent semantic or syntactic function for these prefixes. But careful analysis shows that $i$ is attached to active verbs, and $s a$ - to inactive verbs. These two prefixes appear almost exclusively in nominalized, as well as infinitive clauses. 


\subsection{1 $i$ - on active verbs}

The prefix $i$ - is richly attested in the Man'yôsh $\hat{u}$, as in (25a-b).
(25) a. 楢乃京師乃
佐保川尔
伊去至而
Nara no miyakwo no Sapo kawa $n i \quad i$-yuki itarite
(MY 1/79)
Nara Gen capital Gen Saho river -Loc i-go reaching
'I reached the River Sahokawa in Nara.'
b. 久米能若子我
伊觸家武
礒之草根
Kume no wakugwo ga i-pure-kyem- $u \quad$ iswo no kusa no ne (MY 1/435)
Kume Gen youth Act i-touch-PConj-Adn rock Gen grass Gen root
'the root of the grass that the youth of Kume would have touched.'

A total of 74 occurrences of $i$ - are found in the Man'yôsh $\hat{u}$. The distribution of $i$-parallels that of the case marker ga: both appear in nominalized clauses, i.e. irrealis (mizenkei) conditionals, and -aku nominal, adnominal (rentaikei), and realis (izenkei) clauses.

(26) Quantitative data for prefix $i^{-15}$

\begin{tabular}{|l|l|l|l|l|l|l|}
\hline $\begin{array}{l}\text { Irrealis } \\
\text { (Mizen) }\end{array}$ & $\begin{array}{l}\text { Realis } \\
\text { (Izen) }\end{array}$ & $\begin{array}{l}\text { Adnominal } \\
\text { (Rentai) }\end{array}$ & $\begin{array}{l}\text { Infinitive } \\
\text { (Renyô) }\end{array}$ & $\begin{array}{l}\text { Conclusive } \\
\text { (Shûshi) }\end{array}$ & $\begin{array}{l}\text { Imperative } \\
\text { (Meirei) }\end{array}$ & Total \\
\hline 3 & 5 & 19 & 44 & $(2)$ & $(1)$ & 74 \\
\hline
\end{tabular}

The prefix $i$-attaches to active verbs (all tokens of $i$ - in the Man'yôsh $\hat{u}$ are cited in Yanagida 2007b). There are a number of cases in which $i$ - is prefixed to the unergative verb yuku 'go', but no examples in which $i$ is prefixed to the unaccusative verb kuru 'come'. There are a few examples in which $i$ is prefixed to what appear to be nonagentive verbs, such as (27).
三輪乃
山...
奈良能山乃
山際
Miwa no yama... Nara no yama no yama no ma ni
Miwa Gen mountain Nara Gen mountain Gen mountain among
伊隠万代
道隈
伊積流万代尔
$\boldsymbol{i}$-kakur-u made miti no kuma $i$-tumor-u made $n i$
i-hide-Adn until road Gen bend i-amass-Adn until Loc

(MY 1/17)

'Mt. Miwa. . . until you hide yourself among the mountains of Nara, until you

loom in the bends of the road'

Although we might expect (27) to be interpreted as inactive since the subject Miwa-no yama 'Mt Miwa'is superficially inanimate, the clause is interpreted as personificational by all Japanese commentators. ${ }^{16}$ The use of $i$ - here thus fits with our characterization of OJ as a fluid-S language in the previous section: ostensibly nonagentive verbs may appear with active marking when they have human (or personified) subjects. 
Unlike active marking $g a, i$ - also appears in infinitive (renyôkei) clauses. But in infinitive clauses too, the prefixed verb is unfailingly active in all of the clearly interpretable examples. Of the 44 examples of $i$ - prefixed to a verb in the infinitive, 18 involve the unergative verb $y u k$ - 'go'. The overwhelming majority of $i$ +infinitive clauses have agentive empty (pro) subjects. ${ }^{17}$

In addition to being restricted to active verbs, we see from the table in (23) that $i$ - occurs almost exclusively with the clause types we have identified as nominalized, or in infinitive clauses with agentive pro subjects. None of the 3 potential counterexamples to this generalization are written with phonograms. Kojima et al (1995.3: 369) interpret the single potential imperative example (MYS 3169) as not involving prefixal $i$-, but rather the honorific verb of displacement imas- 'go/come (Honorific)'. ${ }^{18}$ In fact, both of the potential conclusive examples, MYS 1916 and 3885, are open to this same interpretation, as both involve honorific subjects and a verb with the meaning 'go' written in Chinese characters. If this interpretation is correct, there are no examples of $i$ - occurring with imperative or conclusive predicates.

Summing up, the OJ verbal prefix $i$ - is restricted to active verbs. It occurs only with nominalized predicates - the domain we have associated with ergative-active alignment - and infinitives with agentive pro subjects.

\subsection{2. sa- on Inactive Verbs}

The prefix $s a$ - differs crucially from $i$ - in that it appears only on inactive verbs, as in (28).

(28) a. 左奈良戟流 sa-narap-yer-u sa-be.tamed-Perf-Adn falcon Top 'that the tamed falcons would have cried'

b. 左宿之妻屋尔 sa-ne-si tumaya $n i$ 朝庭出立偲 sa-sleep-Pst.Adn bedroom in morning in Top leaving remembering 'remembering, leaving the bedroom where (I) slept'

c. 狭丹煩相吾大王 $\boldsymbol{s} \boldsymbol{a}$-niturap-u wa ga opo kimi sa-shine-Adn I Gen great lord 'my great lord who shines'

d. 椙野尔 左乎騰流雉 sugwi no nwo $n i \quad$ sa-wodor- $u$ kigisi 
cedar Gen field in sa-dance-Adn pheasant

'the pheasant that dances in the cedar-covered field'

e. 河湍尔波

年魚子小狭走

kapa se ni pa

ayu kwo sa-basir-i

(MY3/475)

river shallow in Top sweetfish fry sa-run-Inf

'the young sweetfish running in the river shallows'

There are 30 tokens of the prefix sa- on verbs, including neru 'sleep', niturapu 'shine', pasiru '(fish) run', wodoru '(birds) dance', wataru '(toads) cross', nebapu 'spread roots', narabu '(birds) line up', kumoru 'get cloudy', nituku 'get reddened'. All the verbs are intransitive, and all have non-agentive subjects (aside from ne- 'sleep', all are nonhuman).

(29) Quantitative data for prefix $s a$ -

\begin{tabular}{|l|l|l|l|l|l|l|}
\hline $\begin{array}{l}\text { Realis } \\
\text { (Izen) }\end{array}$ & $-a k u$ & $\begin{array}{l}\text { Adnominal } \\
(\text { Rentai })\end{array}$ & $\begin{array}{l}\text { Infinitive } \\
(\text { Renyô) }\end{array}$ & $\begin{array}{l}\text { Conclusive } \\
\text { (Shûshi) }\end{array}$ & $\begin{array}{l}\text { Imperative } \\
\text { (Meirei) }\end{array}$ & Total \\
\hline 2 & 2 & 14 & 7 & 3 & 2 & 30 \\
\hline
\end{tabular}

Like $i$-, the prefix $s a$ - is used overwhelmingly (25/30 tokens) in nominalized clauses. ${ }^{19} S a$ also occurs in the Man'yôshî as a noun prefix, as in sa-yo 'night', while $i$ - does not. This parallels exactly the distribtion of agreement prefixes in active languages such as Sateré-Mawé (Meira 2006): inactive prefixes occur on nouns and inactive verbs, while active prefixes occur on active verbs only..$^{20,21}$

Alexander Vovin points out to us that one verb in OJ, wataru 'cross', appears with either $i$ - or $s a$-. There are 4 examples of $i$-watar- in the Man'yôsh $\hat{u}$ (MY 1742, 2081, 4101, and 4126), and 6 examples of sa-watar- (MY 800, 971, 1960, 1976, 2450, and 2804). The S of $i$-watar-is [+human] and volitional in all four examples: 'the young woman,' 'Tanabata' (Vega, the weaver star), 'the fisherfolk,' and 'Vega and Altair.' The S of sa-watar- is [-human] in all six examples: ('toads' $(800,971)$, 'a cuckoo' $(1960,1976)$, 'the moon,' 'a teal'. Typical examples of each pattern are given in (30). ${ }^{22}$

（30） a. 安麻能我波 波志和多世良波 曽能倍由母 伊和多良佐牟乎 (MY 18/4126) ama no gawa pasi watasera-ba sono pe yu mo i-watar-as-am-u wo sky Gen river bridge span-if that over from too $i$-cross-Hon-Prop-Adn Conj 'though if one put a bridge across the Milky Way, (they=Vega and Altair) would $i$-cross over on that'

b. 雲間従 kumo ma ywori sa-wataru tukwi no cloud among from $s a$-cross moon-Gen
於保々思ク

opoposiku

faintly
相見子等 (MY 15 /2450) api misi kwo join saw child 
'the girl I saw faintly like the moon $s a$-crossing from among the clouds' I-watar- 'cross (over the bridge)' is agentive, volitional and telic, a stereotypical active verb. $\mathrm{Sa}$-watar- is non-agentive and designates not a completed action, but the moon passing before the speaker's view; in other words, a stereotypical inactive predicate.

We have shown in this section that OJ nominalized clauses show not just an active case marking system, but at least the vestiges of active prefixal morphology. This is evidenced by a strict opposition between active and inactive verbs in both dependent and head marking strategies. Dependent marking of active $\mathrm{S}$ by the case marker $g a$ is in opposition to marking of inactive $\mathrm{S}$ by $n o$ (and, as we discuss in the next section zero). Head marking of active predicates by the prefix $i$ - is in opposition to the prefix $s a$ - on inactive predicates. $^{23}$

\subsection{Marking of Inactive Subjects}

As discussed above, active alignment surfaces in nominalized clauses, but not in main clauses whose predicate takes conclusive form. A main/nominalized split is also attested by unmarked subjects. In nominalized clauses, the internal argument of unaccusative verbs can be unmarked morphologically, while, as we saw in 3.3, the external argument of transitive/unergative verbs is typically marked by Active $g a$. In almost all cases, bare theme subjects of nominalized clauses appears immediately adjacent to the verb (for quantitative data, see Yanagida 2007b). Examples are given in (31).
(31) a. 久木生留
清河原尔
pisakwi Ø opu-ru kiywoki kapara $n i$
(MY $6 / 925)$ catalpa grow-Adn clear riverbank on
'on the banks of the clear river where catalpas grow'
b. 和何則能尔 宇米能波奈知流 waga sono ni ume no pana $\varnothing$ tir-u
比佐可多能 阿米欲里 pisakata no ame ywori (MY 5/822)
I Gen garden in plum Gen blossom fall-Adn Epithet Gen sky from 'in my garden plum blossoms fall from the sky'

In section 5 we show that objects adjacent to transitive verbs are limited to non-branching $\mathrm{N}^{0} \mathrm{~s}$, and are thus analyzable as having undergone incorporation. The incorporation analysis can be extended to non-branching theme subjects, such as pisakwi 'catalpa' in (31a). But branching theme subjects also occur in this position, as shown by ume no pana 'blossom of the plum' in (31b). This indicates that unaccusative subjects have a licensing option not available for transitive objects.

Recall that in 4.2 we described two genitive subject marking strategies in nominalized clauses: active $g a$-marking for agentive subjects high on the nominal hierarchy; and genitive 
no-marking licensed by D, much as in adnominal clauses in modern Japanese (Harada 1971, Miayagawa 1993). A third option, exemplified by (31b), is available for bare subjects of unacusatives that remain in VP. Note that this third option cannot involve an 'absolutive' case, because absolutive should be available for both $\mathrm{S}_{\mathrm{O}}$ (unaccusative subjects) and $\mathrm{O}$ (transitive objects), but as mentioned above and described in more detail in section 5, branching transitive objects do not appear in the VP internal position. Note also that the VP-internal bare subjects in (31) are nonspecific (catalpas, plum blossoms), while subjects marked with no may be either nonspecific as in (20b) (flowers), or specific, as in (30b) (the moon). These facts suggest that examples like (31) involve an impersonal construction, with the bare theme subject licensed in situ inside the VP. Impersonal constructions require a mechanism for assigning nominative case to the theme subject in situ. We propose that $\mathrm{T}$ in OJ nominalized clause may bear a case feature, but only in very restricted circumstances: when T selects 'defective' $\mathrm{v}$, that is, $\mathrm{v}$ lacking a specifier and a case feature of its own (Chomsky 2001). On this view, the bare theme subject in (31b) is assigned case by $\mathrm{T}$ in situ.

Summarizing, the three case marking strategies for subjects of nominalized clauses are shown in $(32){ }^{24}$

(32) a.

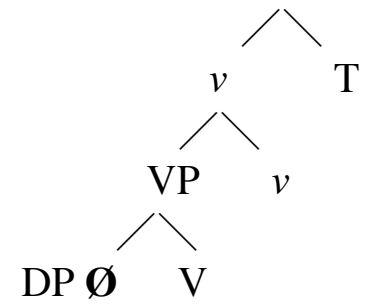

b.

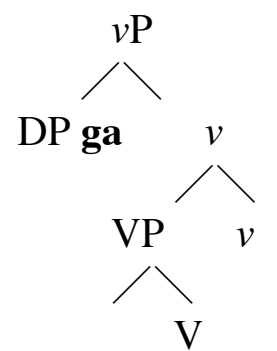

c.

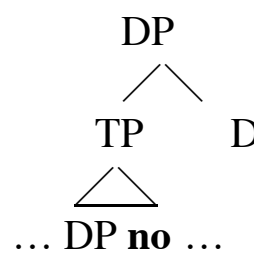

Nonspecific theme subjects in situ are assigned case by T selecting a defective $v \mathrm{P}(32 \mathrm{a})$. Inherent $g a$ is assigned to active subjects in Spec, $v \mathrm{P}(32 \mathrm{~b})$. Genitive $n o$ is assigned by $\mathrm{D}$ to subjects elsewhere. On the assumption that specific theme subjects move out of the VP (Diesing 1992), this explains why specific theme subjects such as 'the moon' in (30b) receive no rather than bare marking. ${ }^{25}$ Under this analysis, no-marking is licensed by a higher head, outside the active alignment system of OJ nominalized clauses.

Turning now to conclusive clauses, unmarked subjects occur freely both as the external argument of a transitive and the internal argument of an unaccusative, as shown in (33).

(33) a. 烏梅能波奈伊麻佐加利奈利

Ume no pana $\varnothing$ ima sakari nar-i.

Plum Gen blossom now at.peak be-Conc

'The plum blossoms are now at their peak.'

b. 見度婆安麻乎等女登母 多麻藻可流美由 
Miwatase-ba amawotomye-domo Ø tama mo Ø karu miy-u. (MY 17/3890)

Look cross-when fisher maiden-Pl pearl seaweed gather appear-Conc

'When I look around, the fishermaidens appear to be gathering pearly seaweed.

While clitic pronouns are uniformly marked by $g a$, and restricted to nominalized clauses, as shown in section 3.3, strong pronouns in subject position are unmarked morphologically and never appear with $g a$.

(34) a. 吾草取有

ware $\varnothing$ kusa $\varnothing \quad$ tor-er-i

(MY 10/1943)

I weed take-Perf-Conc

'I am picking weeds.'

b. 安米都知能 可未乎許比都々 安礼麻多武

Ametuti no kamwi wo kopitutu are $\varnothing$ mat-am-u.

heaven.earth Gen god Acc pray I wait-Presum-Conc

'Praying to the gods of heaven and earth, I will wait.'

Bare objects as in (33b) in conclusive clauses can be analyzed as receiving structural accusative case from v, as proposed by Miyagawa (1989). Bare subjects as in (33a) can be analyzed as receiving nominative case from T, as in modern Japanese (Takezawa 1987).

While the phonological exponence of nominative and accusative case differs, the syntactic mechanisms for case marking in OJ conclusive clauses are essentially the same as modern Japanese. However the sharp difference between the patterns in conclusive and nominalized clauses confirms that $\mathrm{OJ}$ was a language with split alignment: while conclusive clauses follow a nominative-accusative pattern, distinguishing S/A and O, nominalized clauses show an active pattern, distinguishing $\mathrm{S}_{\mathrm{A}}$ and $\mathrm{S}_{\mathrm{O}}$, and grouping $\mathrm{S}_{\mathrm{A}}$ with $\mathrm{A}$. In the next section we turn to object marking in nominalized clauses.

\section{Object Marking in Nominalized Clauses}

This section discusses the two patterns of object marking in nominalized clauses. We focus on adnominal clauses, because of their higher frequency, but the same generalizations hold for the three other types of nominalized clauses.

\subsection{Bare Objects}

As we saw in 2.1, Miyagawa (1989) argues that in Early Middle and Old Japanese, adnominal predicates fail to assign accusative case, and hence an object must be licensed by morphological case in the form of wo in order to avoid a violation of the Case Filter. There are, however, a number of OJ examples in which an adnominal predicate takes an object 
lacking a morphological case, which are thus apparent counterexamples to Miyagawa's (1989) generalization. Yanagida (2007b) shows that in the Man'yôsh $\hat{u}$, there are 90 tokens of transitive clauses whose subject is marked by no or $g a$ and whose object is morphologically unmarked. 55 occur with attributive predicates, as in (35).

(35)a. 佐欲比賣能故何比列布利斯 夜麻能名

Saywopimye no kwo ga pire puri-si yama no na

(MY 5/868)

Sayohime Gen child Act scarf wave-Past.Adn hill Gen name

'the name of the hill where Sayohime waved her scarf'

b. 之加万白水郎之燒塩煙風

Sika-no ama no sipo yak-u keburi

(MY 7/1246)

Shika Gen fishermen Gen salt burn-Adn smoke

'the smoky haze raising when fishermen of Shika burn salt'

However, while bare objects do occur with adnominal predicates, there is a clear pattern to the counterexamples. The bare objects are almost without exception non-branching $\mathrm{N}^{0} \mathrm{~s}$. Of the 55 examples of this type, only one has a phrasal object, MY 2639 in (36): ${ }^{26}$

(36) 憑也君之 吾之名告兼

Tanome ya kimi ga waga na norikyem-u?

(MY 11/2639)

Trust Foc/Q lord Act my name state-PConj-Adn

'Is it because (he) trusts in me, that my Lord has stated my name?'

In relative clauses, where the predicate is realized in the adnominal form, bare objects are systematically non-branching, as in (37) (see appendix 1 for possible exceptions).
玉藻荻 海末通女等
[tamamo kar-u] amawotome-domo
seaweed cut-Adn fisherwoman-P1
'the fisherwomen who are gathering seaweed'

(MY 6/936)

Based on these distributional facts, we propose that bare objects in nominalized clauses like (35) are to be analyzed on analogy with incorporated objects in Chukchee (Spenser 1999):

(38) Chukchee (Spenser 1999)

a. Muri myt-ine-rety-rkyn kimit?-e. we-Abs we-AP-carry-Pres/II load-Instr

'We are carrying the load.'

b. Ytlyg-yn qaa-tym-g?e.

father-Abs deer-killed-3SG

'The father killed a deer.' 
Chukchee is a split ergative language that has two types of derived intransitive constructions with semantically transitive verbs (Spencer 1999). One is the antipassive in (38a), where $O$ is marked with oblique case and $\mathrm{A}$ is absolutive; the second, restricted to $\mathrm{N}^{0}$ objects, is the object incorporation strategy in (38b). The incorporation strategy for objects is also widely attested in American languages displaying active alignment (Sapir 1911).

We propose that OJ uses the incorporation strategy for bare objects, like Chuckchee. Following the basic approach of Baker (1988), non-branching nouns immediately adjacent to an adnominal predicate are incorporated into the verb, and incorporation satisfies the case requiremens of the incorporee. This preserves Miyagawa's generalization that the object of the adnominal predicate is not assigned abstract case in its base position.

\subsection{Wo-marked Objects}

Vovin (1997), developing the hypothesis that OJ is an active language, proposes that wo is an absolutive case marker, because it marks not only the objects of transitive verbs, but also the subjects of non-active intransitives, primarily adjectives. Most of these occur in a pattern involving the adjectival stem plus the suffix $-m i$ :

(39) 久古

$$
\begin{array}{lll}
\text { 久左麻久良 } & \text { 多婢乎久流之美 } & \text { 故非乎礼婆 } \\
\text { kusa makura } & \text { tabi wo kurusi-mi } & \text { kopi wor-eba } \\
\text { grass pillow } & \text { travel Obj painful-mi } & \text { long.for be-when } \\
\text { 'as I am longing for (my wife) travel being painful' }
\end{array}
$$

There are also some examples in which a subject marked by wo occurs with inactive predicates followed by the complementizer to (40):
(40) a.
世間乎宇之等夜佐之等 yononaka wo $u$-si to
於母倍杼母
yasa-si to
omop-e-domo

(MY 5/893)

world Obj dreary-Conc Comp shameful-Conc Comp think-Rls-though 'though I feel the world unpleasant and shameful'
b. 和礼乎 伊都伎麻佐牟等 登比之古良 ware wo itu ki-mas-am-u to topi-si kwo-ra
I Acc when come-Hon-Conc Comp ask-P.Adn child-Affec
'that dear girl, who asked when I would come back'

Miyagawa and Ekida (2003) propose that examples like (40a-b) are instances of exceptional case marking (ECM), on the assumption that wo is the spellout of abstract case assigned by the matrix verb. Yanagida (2006) argues that OJ has no ECM construction, and that wo-marked subjects in the pattern with to-clauses as in (40a-b) are arguments of the higher 
verb (which, as we observe, has a nominalized inflection, realis and adnominal respectively). ${ }^{27}$ Under either analysis, wo is assigned not by the embedded intransitive predicate, but by the matrix transitive verb. Note that this leaves open the status of the NP wo. . .-mi pattern, to which we return at the end of this section.

The strongest argument against the analysis of wo as an absolutive marker is that the subject of a non-active intransitive verb is never marked by wo in adnominal, realis or irrealis conditionals, or $-a k u$ nominal clauses. It is either morphologically unmarked or marked by genitive $n o$, as discussed in section 4 and exemplified by (41-42).

(41) a. 多都多夜麻美麻知可豆加婆

Tatuta yama mi-ma Ø tikaduk-a-ba

(MY 5/877)

Tatsuta mountain Hon-horse comes.near-Irr-if

If your horse draws near the Tatsuta mountain'

b. 梅 花

咲散苑尔

吾将去

Ume no pana $\varnothing \quad$ saki tir-u sono $n i \quad$ ware yuk-amu.

(MY 10/1900)

Plum Gen blossom bloom fall-Adn garden to I go-will

'I will go to the garden where plum blossoms bloom and fall.'

(42) a. 此暮

柘之左枝乃

流来者

Kono yupupye tumo no $s a$-yeda no nagare k-o-ba

(MY 3/386)

this evening mulberry Gen branch Gen flow come-Irr-if

'if this evening a mulberry branch comes flowing down'

b. 宇能花能

佐久都奇

$u$ no pana no

sak-u tukwi

(MY 18/4066)

utugi Gen blossom Gen bloom-Adn month

'the month when the utsugi blossom is in bloom.'

If wo was an absolutive case marker, we would have no explanation for why the subject is never marked by wo in the contexts given in (41-42).

The particle wo differs significantly from its descendant $o$ in modern Japanese in that it marks not only direct objects, but all kinds of VP-internal arguments including quasi-adjuncts (cf. Motohashi 1989). In (43a), wo marks the goal argument, and in (43b-e) source, locative, and time adjuncts. In (43f-g) wo co-ccours with a locative adjunct marked by $n i$, 'in/at'.

(43) a. 象小河乎行見為

Kisa no wogapa wo yuki-te mi-m-u tame

(MY 3/332)

Kisa Gen stream Obj go-ing see-Presum-Adn purpose

'in order to go and see the Kisa stream.' 
b. 奈良乎伎波奈礼

Nara wo k-i panar-e

(MY17/4008)

Nara Obj come-Inf leave-Inf

'coming away from Nara.'

c. 川邊乎春雨吾立沾等

kapabe wo parusame ni ware tati nuru to

(MY 9/1696)

riverside Obj spring rain in I stand get.drenched Comp

'that I am standing getting drenched in the spring rain on the riverside.'

d. 雨零夜乎霍公鳥鳴而去成

Ame no puru ywo wo pototogisu naki-te yuk-u nari.

(MY 9/1756)

Rain Gen fall night Obj cuckoo cry-ing go-Adn is

'Through the night when the rain falls, a cuckoo flies crying.'

e. 秋風乃寒朝開乎佐農能岡将超公

aki kaze no samuki asake wo Sanu no woka kwoyu-ram-u kimi (MY 3/361)

autumn wind Gen cold morning Obj Sanu Gen hill cross-Pr.Conj- Adn lord

'my lord, who would be crossing over the Sanu hill in the cold morning wind.'

f. 安我許呂母 之多尔乎伎麻勢

Aga koromo sita ni wo ki-mas-e.

(MY 15/3584)

my robe underneath Loc Obj wear-Hon-Imp

'Wear this robe of mine underneath.'

g. 安治佐為能夜戟 佐久其等久 夜都与尔乎 伊麻世

Adisawi noyapye saku gotoku yatuyo ni wo imase.

(MY 20/4448)

hydrangeas Gen eight bloom as eight generations Loc Obj live-Imp

'As hydrangeas have eightfold flowers, so may (my lord) live for eight

generations.'

These facts make it difficult to analyze wo merely as the spellout of VP-internal structural case. In (43f-g), for example, it is unclear why structural case would be required for PPs headed by the locative postposition $n i$.

This property correlates with the generalization about the word order of OJ clauses containing wo mentioned in section 1. As shown by Yanagida (2006), the relative position of the subject and the wo-marked object is such that the latter always precedes the former, as shown in (4) and (19a). ${ }^{28}$ Additional examples are given for adnominal (44a), - $a k u$ (44b), and realis (44c) clauses below. (See Appendix 2 for a preliminary correlation of conjugational forms with wo-marking in the Man'yôshu.) 
a. 和礼乎也未尔也伊毛我古非都追珠 安流良牟

Ware wo yami ni ya imo ga kwop-i-tutu aru ram-u?

(MY 15/3669)

I Obj dark in Q wife Act longing.for be PConj-Adn

'Would my wife be longing for me in the dark?

b. 伎美乎 安我麻多奈久尔

kimi wo a ga mat-ana-ku ni

(MY 17/3960)

lord Obj I Act wait-not-Inf Loc

'without me waiting for you'

c. 草香乃山乎暮晚尔吾超来者

Kusaka no yama wo yupugure $n i$ wa ga kwoye ku-re-ba

(MY 8/1428)

Kusaka Gen mountain Acc twilight in I Act cross come-Rls-Cond

'when I cross over Kusaka mountain in the twilight'

Yanagida (2007a) lists 65 examples of XP wo preceding subjects. In contrast, the Man'yôsh $\hat{u}$ contains only one example interpreted as involving the order Agent $g a$. . XP wo. ${ }^{29}$

In addition to this regularity about their word order, it has been observed by Motohashi (1989) that wo-marked phrases tend to be definite. In fact the generalization is slightly broader: wo-marked phrases are specific. This can be shown by the fact that $w h$ pronouns can be marked by wo, but when they are, they receive a specific interpretation in contrast to bare wh pronouns. This is shown in the contrast between the following two examples.

(45) 真木乃板戸乎押開思恵也出来根 後者何将為

Maki no itatwo wo osi piraki siweya ide ko-ne noti pa nani se-m-u? (MY 11/2519) wood Gen door Obj push open damn out come-Des after Top what do-Presum-Adn 'Pushing open the door (I say) “Come out, dammit!” Then what will (I) do?'

(46)

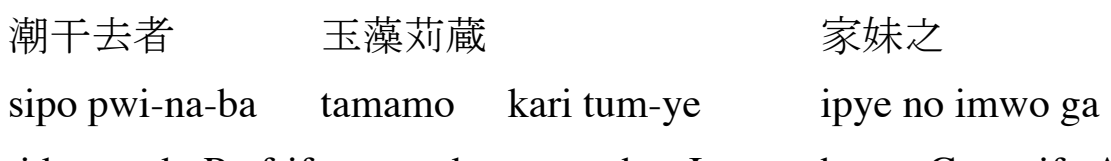

tide recede-Perf-if seaweed cut gather-Imp house Gen wife Act

濱衣乞者何矣示

pamaduto kop-aba nani wo simyesa-m-u?

(MY 3/360)

shore.gift want-if what Obj proffer-Presum-Adn

'If the tide has gone out, cut and gather the precious seaweed! If my wife at home asks for gifts from the shore, which (other) shall I offer her?'

In (45), the universe of things the speaker might do is completely undefined in previous discourse. In (46), in contrast, the set of items that the speaker might offer his wife is defined as pamadutwo 'gifts from the shore'. In this case nani wo 'what/which Obj' picks out specific items from that set. 
Yanagida (2006) analyzes the properties of adnominal clauses as in (47):

(47) Case and argument realization in OJ

(i) $G a$-marked subjects stay in the base external argument position (Spec, $v \mathrm{P})$.

(ii) Bare objects are incorporated into the verb.

(iii) Wo-marked objects obligatorily move to the outer Spec of $v \mathrm{P}$, to check their [definite] feature.

Here we revise this analysis to take into account the new data reviewed in this section. First, the properties in (47) apply to nominalized clauses generally. Second, movement of wo-marked phrases is not triggered by a definite feature, since wo-marked XPs may include wh phrases and PPs, among other items. Instead, we would like the specificity of wo-marked phrases to be a byproduct of their movement.

We can capture these generalizations by returning to the basic insight of Miyagawa (1989): that the verbal projection in nominalized clauses does not assign structural case. We saw in section 4 that under the active analysis the $g a$-marked agent in nominaized clauses remains in Spec, $v \mathrm{P}$, and receives inherent case there. Following Miyagawa's original proposal, we hypothesize that [nominal] $v$ does not bear an accusative case feature. This leaves two options for case licensing objects: incorporation, in the case of nonbranching objects, or case assignment by a head above $v \mathrm{P}$.

As we have seen, wo is realized to the left of the external argument, indicating that it is indeed assigned by a head above $v \mathrm{P}$. There are two possible candidates for the identity of this head. One is T; this would bring OJ into line with analyses of certain ergative languages where absolutive case is assigned by $\mathrm{T}$ (Aldridge 2004, Legate 2008). The drawback of this approach is that OJ wo, as discussed above, does not show the distribution of a standard absolutive case: it does not appear on the subjects of inactive (or any kind of intransitive) verb. A possible way around this difficulty is to expand the analysis of nominative case assigned by $\mathrm{T}$ in nominalized clauses presented in section 4.4 . We proposed there that bare theme subjects are assigned nominative case by $\mathrm{T}$ selecting a defective $v \mathrm{P}$ in nominalized clauses. It could be hypothesized that nominative case is also assigned by $\mathrm{T}$ selecting nondefective, that is, transitive or unergative $v \mathrm{P}$, but that nominative in this instance is spelled out as wo. An analysis along these lines seems possible, but it has the flavor of a stipulation, so we will not pursue it further here.

The second option is that wo is assigned by a functional head between $v$ and $\mathrm{T}$. We propose that wo-marked DPs reside in the specifier of AspectP. Washio (2004) shows that aspect selection in $\mathrm{OJ}$ was sensitive to transitivity, suggesting that AspectP, rather than $v \mathrm{P}$, was the locus for a [ \pm transitive] feature. We hypothesize that [+transitive] Aspect in OJ bears 
an EPP feature that attracts the highest non-inherently case marked argument in the verbal projection to its specifier, as shown in (48).

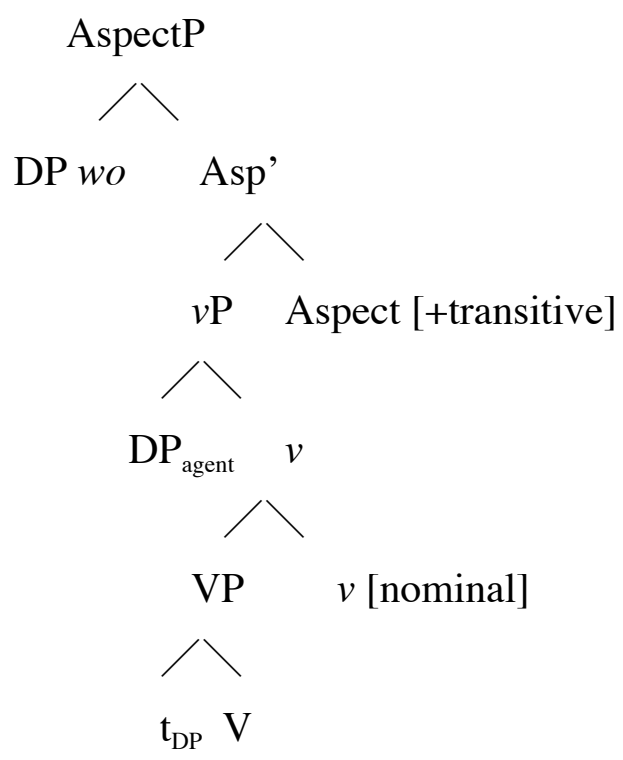

Diesing's (1992) hypothesis that bare NPs extracted from the nuclear scope of the clause receive a specific interpretation explains the [specific] property of wo-marked phrases.

Note that this analysis correlates wo-marking and the position of wo-marked arguments with the presence of [+transitive] AspectP in nominalized clauses. We leave open the question of wo-marking in the other major clause types: conclusive, infinitive, and imperative. We show in Appendix 2 that wo-marking also occurs in these clauses, but as observed by Miyagawa (1989) and Miyagawa and Ekida (2003), it is more restricted. In conclusive clauses, it is largely restricted to propositional attitude verbs of thinking or saying, while in imperative clauses $w o$-marking seems to have been a mid- $8^{\text {th }}$ century innovation, probably triggered by the phonological merger of certain infinitive and imperative endings.

The AspectP analysis extends naturally to Vovin's characterization of the wo. . - mi pattern in (39). AspectP is identified as the head of participial-type nominalization in analyses such as Embick (2004) and Alexiadou and Anagnostopoulou (2007). Unlike the object Equi wo-marking pattern in (40), the wo-marked subject in wo . .-mi clauses is not susceptible to a matrix object (or ECM) analysis, because wo . . -mi clauses are adjuncts, typically expressing reason or cause. We analyze the wo...-mi pattern as adjunct AspPs, analagous to Acc-ing gerunds such as 'travel being painful' in English:

(49) [AspP tabi wo [vP kurusi ]mi ] kofi wor-eba travel Acc painful-mi long.for be-when

'as I long for my wife, travel being painful'

On this analysis, $-m i$ is the spellout of the head of [+transitive] AspP. The stipulation that $-m i$ is [+transitive] may have a diachronic motivation, as one etymology for $-m i$ derives it from 
the infinitive of the transitive verb $m i$ - 'see'. Wo... -mi clauses do not contain tense, which is consistent with our hypothesis that wo is assigned by a functional head lower than T.

Summarizing the results of this section, we have shown that OJ had two mechanisms for case marking objects in nominalized clauses: incorporation and wo-marking above $v \mathrm{P}$. The inability of $v$ in nominalized clauses to assign accusative case is a direct extension Miyagawa's (1989) original hypothesis. More generally, as we discuss in detail in 6.2, the active alignment propeties of OJ nominalized clauses fit into the crosslinguistic pattern identified by "nominalist” analyses of non-accusative alignment such as Johns (1992) and Kaufman (2008). [Nominal] $v$ is unable to check the case feature of the object. Objects must therefore be case licensed by other strategies: assignment of 'absolutive' case by T (Aldridge 2004, Legate 2008), default absolutive (Legate 2008), incorporation, or, in the instance of OJ, case assigment by a functional head above $v \mathrm{P}$.

\section{Alignment and Nominalization in Diachronic and Typological Perspective}

We have seen that OJ active alignment is restricted to the clause types we have called 'nominalized': adnominal (rentaikei), nominal complements in -aku, and realis (izenkei) and irrealis (mizenkei) conditionals. We have shown how the nominalized properties of these clauses are intimately linked with their active properties: nominalized clauses assign inherent agentive $g a$ in Spec, vP, and [transitive] Aspect in these clauses attracts complements to a position above the external argument, where they receive wo-marking. In 6.1 we discuss the diachronic sources for the nominalized clause patterns in OJ. In 6.2 we show that nominalizations are widely attested crosslinguistic source for non-accusative alignment. We focus on a specific case, Cariban languages as analyzed by Gildea $(1998,2000)$, and point out that it suggests a possible source for the wo-marking pattern in OJ. 6.3 discusses changes possibly already underway in OJ, involving the genitive/subject marker no.

\subsection{The Nominalizing Origins of the Adnominal and Irrealis Conditional Endings}

Konoshima (1962) seems to have been the first to argue that the nominalizing or juntaigen 'quasi-nominal' function of the adnominal endings was primary, and its NP modifying function secondary. Adnominal clauses in OJ have the distribution of $[+\mathrm{N}]$ categories, i.e NPs and uninflected adjectives. Like NPs, they may serve as subject or object of the clause, and be followed by case markers. The NP modifying function of adnominal clauses is parallel to uninflected adjectives, which were able to directly modify NP in OJ. ${ }^{30}$ As we saw in 2.1, Miyagawa (1989) also analyzes OJ and MJ adnominal clauses as [nominal]. 
Of the remaining three clause types that we have labeled nominalized, two are held to be diachronically derived from the adnominal. Nominal complements in $-a k u$ are derived by Ohno (1953) from the adnominal form of the verb plus a noun *aku, e.g. $y u k-u$ 'go-Adn' + aku > yukaku 'going;' kuru 'come-Adn' + aku > kuraku 'coming., ${ }^{31}$ Whitman (2004) derives the irrealis endings (-e for quadrigrade, -ure for other conjugations) from the proto-Japanese form of the adnominal ending *-or.

The irrealis (mizenkei) base in $\mathrm{OJ}$ is shown by Ohno to be of heterogeneous origin. It results from reanalysis of the initial vowel in various auxiliaries and suffixes as the ending of the irrealis (mizenkei) base. In the case of the irrealis conditional, the ending was $*$-a, probably related to the nominalizing suffix *-a hypothesized by Sakakura (1966: 286-303). This ending is preserved in such noun-verb pairs as tuk- 'build up' : tuka 'mound;' mur(e)'gather' : mura 'group, village.' The irrealis conditional appears productively only before the conditional particle $-b a$, which Ohno derives from locative $n i+$ topic marker $p a$. If Ohno's analysis is correct, it confirms the original nominalizing function of $*_{-} a$, as we expect locative $n i$ to select a [nominal] form.

Summing up, the four clause types that show active-ergative alignment in OJ all derive from nominalizations: the adnominal, nominal, and realis conditional from the $\mathrm{pJ}$

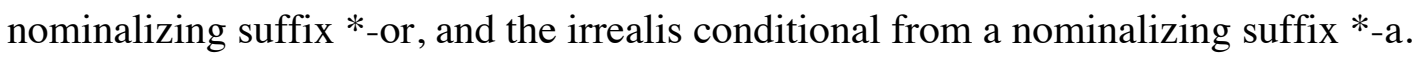

\subsection{Nominalizations as Sources for Alignment}

A number of linguists have proposed nominalization structures as the diachronic source for non-accusative alignment, particularly for languages that show syncretism of agent and gentive marking. Proposals of this sort are made for Mayan (Bricker 1981), Austronesian (Starosta et al 1982; Kaufman 2007), Cariban by Gildea (1998, 2000). Johns (1992) develops a synchronic account of Inuktitut ergativity based on nominalization. ${ }^{32}$ The starting point for these 'nominalist' accounts of non-accusative alignment is similar to Miyawgawa's synchronic treatment of adnominal clauses in OJ: nominalized clauses are unable to assign structural accusative case. Depending on the features of T, or whether T is present, nominalized clauses may also be unable to assign structural nominative. The non-accusative alignment properties of nominalizations can be seen in familiar examples, such as English derived nominalizations. Thus in the city's destruction by the barbarians, the nominal projection assigns neither accusative nor nominative case; the external argument is licensed by the preposition by, and the internal argument is assigned genitive case by $\mathrm{D}$.

From a diachronic perspective, the nominalist hypothesis holds that non-accusative alignment results when nominalized clauses are reanalyzed as main clauses. Gildea (1998) 
discusses a particularly rich range of alignment and word order patterns resulting from reanalyzed nominalizations in Cariban. We focus here on what Gildea (1998: 190-6, 2000: 85-88), citing Franchetto (1990), calls the 'De-ergative' system in the Cariban languages Panare and Kuikúro. The source for this system in earlier Cariban, according to Gildea, was an object nominalization selected by the matrix copula. In this source structure, the agent remained within the nominalized VP, while the notional object argument of the nominalized verb corresponded to the subject of the matrix copula. Let us first look at a modern Panare example of the de-ergative pattern $(50) .^{33}$
(50) yu-noh
$\mathrm{p}$
n -a'kama-p t -hpë
mën
(Gildea 2000: 86)
1-grandmother dead Agt.Foc-tell-Iter-Pst it
'My late grandmother told it over and over.'

(51) shows the source structure that Gildea (2000: 88) posits for the de-ergative pattern:

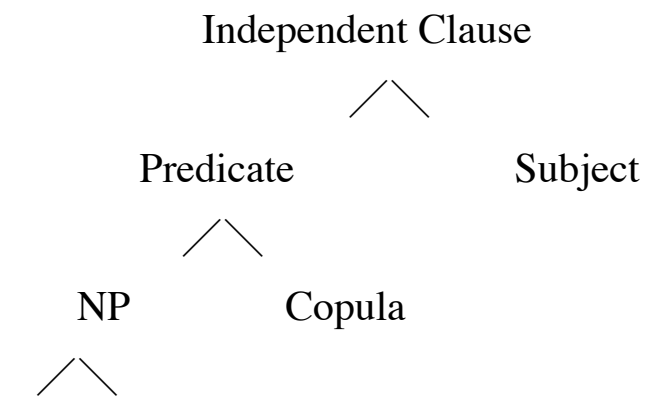

Source: Poss n-V-Nmlzer

Result: A DErg-V-T/A (Auxiliary) O

The reconstructed source for a sentence like (50), for example, would involve an object nominalization with the meaning 'what my grandmother told over and over again.' 'It' is predicated of this nominalization by the matrix copula. The complete reconstructed source for (50) would thus have the form 'It is [what my grandmother told over and over again].' In Panare, this source structure is reanalyzed as monoclausal, as shown in (51): the copula is reanalyzed as an auxiliary, the nominalization as a verbal projection containing the verb and the external argument (A) in its base postion, and the original subject as the object $(\mathrm{O})$. Gildea (2000: 98) cites constituency tests showing that $\mathrm{O}$ in the Panare de-ergative construction is external to the minimal projection containing A and the verb.

Gildea's account shows how reanalysis of a nominalization structure can result not just in non-accusative alignment, but in a crosslinguistically marked structure. The basic property of this structure is exactly the same as the property of wo-marked clauses in OJ identified by Yanagida (2006) and discussed in 5.2: the object surfaces ouside the minimal projection containing the external argument and the verb. 
Japanese is not a member of a clearly defined language family of great time depth like Cariban, so in reconstructing earlier Japanese syntax we are confined to the technique of internal reconstruction. However we would like to conclude this section by suggesting the possibility that a reanalysis similar to (51) was the diachronic source of the O-wo S-gen V pattern in OJ. The etymological source of the object marker wo has long been debated, but one fact that has not been observed is that the shape of this particle is identical to the existential verb root $w o$-, which appears in the OJ verbs wor- 'exist, sit' and wi- 'be at, sit. ${ }^{134}$ We suggest that that wo originates as the copular verb in a construction parallel to the Cariban de-ergative pattern.

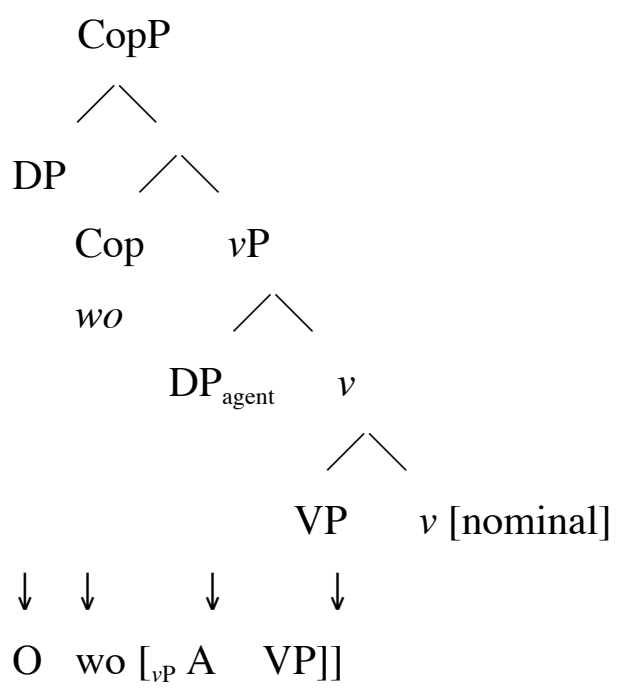

In (52), as in (51), a source structure involving copula+nominalization is reanalyzed as monoclausal. The projection containing the original copula is reanalyzed as AspP, similar to the reanalysis of the copula as an auxiliary in Cariban. The rest of the structure remains the same. The most controversial aspect of (52) is likely to be the hypothesis that earlier Japanese may have had a right-branching copula. But even at the OJ stage, Japanese gives evidence for right-branching functional projections, such as the aspectual auxiliary ari 'be', the modal auxiliary $e$ 'be able', and negative imperative $n a$, all of which appear to the left of the lexical verb (Whitman 2005).

In this section we have presented typological evidence suggesting that both the alignment and transitive constituent structure properties of OJ nominalized clauses fit into a larger crosslinguistic pattern. Nominalized clauses may provide the diachronic source for non-accusative alignment, and for a synchronic pattern where the object appears outside the minimal projection containing the subject and the verb. 


\subsection{After OJ: the Reanalysis of no as Nominative}

As we have seen, in OJ the subject can be marked by ga or no, but their distribution is quite different. $G a$ marks the external argument of transitive/unergative verbs, but not the internal argument of an unaccusative. No, on the other hand, patterns like a nominative case marker in that it can mark both the external argument of a transitives and the internal argument of intransitives, as we saw in section 4.1:

(53) a. 弥騰里兒能知許布我其登久

midorigwo no ti kop-u ga gotoku

(MY18/4122)

infant Gen breast desire-Adn Agt like

'like a child desires its mother's milk'

b. 真木乃立荒山中尔

makwi no tatu ara yama naka

(MY 3/241)

tree Gen stand rough mountain inside

'in the rough mountains covered with trees'

In (53a), no marks the subject of the transitive and in (53b) it marks the subject of the unaccusative. The two particles $g a$ and no behave differently at the syntactic level as well. Yanagida (2006) shows that when the subject and object are case-marked, the object always precedes the subject, as we saw in 4.2. But there are a few cases of no-marked subjects which violate this generalization. These are illustrated in (54) (other Man'yôshû examples are 196, $2772,2831,3689)$.
a. 春雨 乃
与久列杼
吾等乎沾
parusame no yokure-do
ware wo nuras-aku
(MY 9/1697)
spring rain Gen avoid-although
I Obj
drench-Adn
'(that) the spring rain, however (I) try to avoid it, drenches me.'

\section{b. 彼所毛加 人之 \\ Soko mo ka pito no} 吾乎事 将成 wa wo koto nas-am-u?
That too Q people Gen
I-Obj things say-Conj-Adn
'Do people say that of me too?'
In (54) no appears in a position preceding wo. Although this configuration is rare in the Man'yôsh $\hat{u}$, it becomes widespread in kunten glosses written early in EMJ. The following examples are taken from the Konkômyô Saishô Ôkyô 'The Sutra of Golden Light' (kunten text ca. 830; interpretations are based on Kasuga 1969).

(55) a. yoki wotoko yoki womina no ... sinkyau no kokoro wo nasamu good men good woman Gen/Nom reverent Gen mind Acc produce 
'(that) good men and good women... might produce a reverent mind'

b. yoki wotoko yoki womina no ... Sanzyou dou wo syusemu

good man good woman Gen/Nom Triyāna way Acc practice

'(that) good men and good women might master the Triyāna doctrine'

Another significant development revealed in this early EMJ text is that subject marking $g a$ is only used in the form of aga 'I.Subj' and naga 'you.Subj'; nominal subjects are never marked by $g a .^{35}$ In the Man'yôshû the pronominal subjects aga and naga are strictly adjacent to the verb, but in the Konkômyô Saishô Ôkyô they can occur in sentence initial position, preceding a wo-marked object, as shown in (56).

(56) a. wa ga katari wo idas-are-mu

toki...

I Agt words Acc produce-Pass-Presum time

'the time when I (was able to) produce words'

b. na ga yoku kono Myaugyau-wau wo rufu-si...

(K 8-15:146)

you Agt successfully this Myaugyau-wau Acc propagate

'you propagating this Myô-kyô successfully...'

It appears, from this data, that $g a$ as an active case marker, in the formal sense we have defined in this paper, was lost early in the EMJ period. The limitation of $g a$ to first and second person pronouns way probably a step on the way in this process. (Recall that in many languages, active case is restricted to first and second personal pronouns.)

Finally, in section 4.3.1 we saw evidence for a pronominal active prefix $i$ - in OJ In the Konkômyô Saishô Ôkyô, however, there are many instances of the postnominal particle $i$ marking the agent arguments of transitive/unergative verbs, as shown in (57) below:

(57) Ware i ... ti ga sakai wo tuutatus-eri.

I Nom wisdom Ga border Acc pass-Rslt

'I passed through the border of wisdom.'

As we saw in 2.3.1, Vovin (1997) analyzes the postnominal particle $i$ in OJ as an active (agentive) marker. However considering the fact that early kunten texts were heavily influenced by Korean glossing for Chinese Buddhist texts, it is possible that subject marking $i$ is a borrowing of the Korean nominative marker $i$. This would be consistent with the view of Vovin (2005) that the much rarer subject marker $i$ found in OJ is a Korean loan. In any case, EMJ $i$ patterns like no, rather than OJ $g a$, in that it appears in a position preceding wo.

The word order facts suggest that Japanese was well on the way to developing accusative alignment even in nominalized clauses by the early EMJ period. Transitive subjects, regardless of the phonetic form of their case marker, were assigned case in a position higher 
than wo-marked objects. This case was spelled out as ga (on first and second person pronouns) $i$ (on some agentive subjects) or no (the elsewhere case).

\section{Conclusion}

In this paper, we have proposed that Japanese at its oldest attested stage, central dialect OJ of the $8^{\text {th }}$ century, shows evidence of active alignment. OJ displays a split in case marking beween main (conclusive) and nominalized clauses. Main conclusive clauses are accusative. Nominalized clauses display active alignment in case marking and crossreferencing of arguments on the verb through prefixation. The distinctive $\mathrm{O}$ wo $\mathrm{S} \mathrm{V}$ pattern of transitive nominalized clauses identified by Yanagda (2006) is consistent with a formal analysis of active alignment where the external argument receive inherent active case in situ. Crosslinguistic comparison shows that nominalization is a widespread source for non-accusative alignment, as well as for a pattern where the surface postion of the object is higher than the subject.

\section{Appendix 1: Bare Objects in Relative Clauses}

The possible counterexamples to Miyagawa's generalization in (5) are given below. Phrasal objects can appear with adnominal relative clause predicates when they occur in main clause initial position, as shown in (58).

(58) a. [Tomo-no Ura-no iso-no murwo-no kwi-Ø] [[ pro mimu-goto-ni api-misi] imo]pa Tomo Bay Gen beach Gen cypress Gen tree see whenever see maid-TOP wasura-ye-me yamo

(MY 3/447) forget-AUX Q

'Whenever I see the cypress-tree by the beach beside Tomo Bay, would I ever forget my dear who stood by me and saw it?'

b. [Kadusika no Mama no iriyeni utinabiku tamamo-Ø][[pro kari-kyemu]tekwona] si Kazushika Gen Mama Gen inlet in wave seaweed cut-AUX maid FOC omopo-yu

(MY 3/433) remembee-AUX

'I remember the maid who gathered the waving seaweed in the inlet of Mama of the Kazushika region.'

The phrasal objects in clause initial position in (58) are left dislcocated to the left peripheral topic position. A left dislocated topic may serve as what is known as jokotoba 'introductory stanza', an important rhetorical device used throughout the Man'yôsh $\hat{u}$. The introductory 
stanza prefaces the contents of the succeeding verse. Note that a bare oblique NP can also be left dislocated out of a relative clause with an intransitive predicate, as in (59).

(59) [Yupuyami-no konopa Ø] [[pro komoreru] tukwi] matu gotosi. (MY 11/2666) evening-dark Gen tree-leave hide moon wait like 'I feel as if I were waiting for the moon hidden behind an evening tree.' In OJ, not only the object of a transitive verb but the locative adjunct of an intransitive verb can be morphologically bare. The bare NP in (59) is not a counterexample to Miyagawa's generalization on two counts: first, it is an adjunct, thus not assigned structural case; second, it occurs in main clause initial position and thus may be interpreted as left dislocated.

In other cases of bare NP adjuncts we know that the first explanation is at work. The two bare NP adjuncts ama no sita 'the land' (lit. 'under the heavens') and tamapoko-no miti 'road' can appear inside an adnominal clause: there are 4 occurrences of ama-no-sita and 6 of tamapoko-no miti, as illustrated in (60). (For other examples, see MY 162, 207, 230, 1738, 3276, 4006, 4098, 4465.)

(60) a. [Opotu no miya ni ama no sita $\varnothing$ sirasime-kyem-u] sumyeroki (MY 1/29) Otsu Gen Palace to heaven Gen under governed emperor 'the emperor who came to the Palace of Otsu to rule the land.'

b. naku tori no kowe mo kikoye-zu [tamapoko no miti yuku] pito (MY 2/207) sing bird Gen sound Foc hear-not Epithet Gen street go people 'people who pass on the street, not hearing the songs of birds'

Ama no sita 'land' and tamapoko-no miti 'road' are analayzable as compound nouns, and thus probably not true counterexamples. The word tamapoko belongs to the category of so-called makura kotoba 'pillow words' or epithets, which are fixed designators of the referent that follows them. They are conventionalized, and often unintelligible. There are two genuine counterexamples, listed below.

(61) a. [Akikaze no samuki asaake wo Sanu no oka $\varnothing$ kwoyu-ramu] kimi ni fall wind Gen cold early morning Obj Sanu Gen hill cross-AUX lord to kinu kasa masi wo (MY 3/361) dress lend-Aux-Excl 'In the early morning when the autumn wind is cold, I wish to lend my dress to the lord who is going over the hill of Sano.'

b. [Warafa ga mi ni pa yupipata no swode tuke goromo $\varnothing \mathrm{ki}$-si] young Gen me at Top color-printed Gen sleeve with clothes wear-P.Adn 


\section{I-EXCL}

'At a young age, I was like a child wearing clothes with sleeves printed in colors.'

\section{Appendix 2: Wo in Imperative and Conclusive Clauses}

803 instances of wo-marked objects in the Man'yôsh $\hat{u}$ are listed in Koji (1988). (These do not include wo-mi constructions, wo used for makurakotoba epithets, and occurrences with other particles such as wo-ba. $)^{36}$ Most of the 803 tokens appear in nominalized clauses, as expected; that is, the predicates in the irrealis (mizenkei) conditionals, continuative (renyôkei), adnominal (rentaikei), realis (izenkei), and -aku nominal clauses. There are, however, some exceptions: 6 instances of wo-marked objects appear with the predicate in the imperative form (62), and 34 with the conclusive predicate in main and purposive clauses marked by to (63-64).

Imperative: (6 tokens)

(62) Aki no

$$
\text { yupupye wa ware wo sinopas-e. }
$$

(MY 20/4444) autumn Gen evening Top me Obj remember-Imp

'(On) autumn evenings, remember me.'

Main clause conclusive: (23 tokens)

(63) a. Putari site musubisi pimo wo pitori site are pa toki mi-zi.

(MY 12/2919) together tied cord Obj alone I Top untie try-Neg.Conj.Conc 'The sash cords that we tied together, I will surely not untie alone.'

b. Ware-wo wasuras-u na. (MY 14/3457) me-Obj forget-Conc Neg.Imp 'Don't forget me.'

Conclusive in to-marked clauses: (11 tokens)

(64) tama wo pirop-u to (MY 7/1220) jewel Obj find-Conc Comp 'in order to find the jewel'

There are additional 119 instances of wo-marked objects that precede to-marked clauses, but they may be taken as arguments of ellipted higher verbs such as omopu 'think' or ipu 'say'.. In these examples, wo-marked objects are arguments of non-conclusive, non-imperative clauses, as illustrated in (65).

(65) $\mathrm{Kimi}_{\mathrm{wo}_{i}}\left[\mathrm{pro}_{\mathrm{i}}\right.$ sakiku are to] (omopite) ipapibe sue-t-u. (MY 17/3927) lord Obj safe be Comp (thinking) offering vessel place-Perf-Conc 
'(Thinking) of my lord, 'May he be safe,' I placed the offering vessel.'

As discussed in section 5.2, we assume that OJ has no ECM constructions; the wo-marked subject of the inactive verb is in fact the argument of the higher verb omopu 'think', which has been deleted in (3927), but standardly interpreted as underlyingly present in this and similar examples. There are also in Koji (1988) at least 3 examples of wo-marked objects that precede to-marked clauses; these however should be taken as dislocated topics (MY 2/148, MY 10/2228, MY 20/4300). They are not arguments of embedded to-marked clausses, but serve as jokotoba 'introductory stanzas', as discussed above. There are also 4 occurrences of wo-marked objects embedded in -rasi clauses, as in (66) (MY 13, 3145, 4111, 4427).

(66) Wagimoko si a wo sinop-u ras-i.

(MY 12/3145)

my.girl Emph me Obj think-Conc seem-Conc

'My girl seems to be thinking of me.'

These data show that wo marking had spread beyond nominalized clauses in the OJ period, but its distribution appears quite restricted. Most instances of wo marking with Conclusive predicates involve to 'that' clauses such as (64-65), and many of the conclusive main clause examples such as (64a) involve topicalized objects. This suggests a scenario for the spread of wo marking to conclusive clauses. Topicalized wo-marked objects with propositional attitude verbs selecting a to-clause complement may have been reanalyzed as extracted directly from the to-clause, especially in contexts like (65) where the higher verb is dropped.

Support for this scenario comes from the rarity of wo-marking in imperatives. Koji (1988) cites only 6 examples. 4 of these (MY 4009, 4444, 4177, and 4179) are from songs in volumes 17-19 of the Man'yôsh , composed by Ootomo no Yakamochi or his associates in the period around 750. Of the remaining two examples, MY 3764 was composed around the same period by Nakatomo no Yakamori, while wo in MY 2352 is analyzable as a vocative particle. This suggests that wo-marking in imperatives was a relatively late innovation. It may have arisen by analogy with wo marking in infinitive clauses, triggered by a phonological merger. Four of the 5 clear examples cited above involve imperative predicates with root final $-s$; imperative $-y e$ and lower bigrade infinitive $-e$ had merged after $/ \mathrm{s} /$ well before the $8^{\text {th }}$ century.

\section{Notes}

1 This paper follows in general the transcription and glossing conventions for Old Japanese in Frellesvig and Whitman (2008); however we gloss inflectional endings only when crucial for the argument. Our data is taken from the Man'yôshû (compiled mid-8th century), based 
primarily on Yoshimura's electronic text as well as the editions by Nakanishi (1978-1983), Kojima et al. (1995) and Satake et al. (2002). Examples are cited only when the morpheme crucial for the argument is attested in phonogrammatic form (transcribed in italics); material attested logogrammatically is transcribed in simple text.

${ }^{2}$ The term "nominal" for nominalized clauses in -aku follows Wrona (2008). Wrona shows that $-a k u$ nominal clauses fulfill many of the subordinate clause roles taken on by adnominal clauses in EMJ texts. For the standard view that the nominal ending is historically derived from the adnominal, see section 6 .

${ }^{3}$ Vovin (2005: 111-116) revises this analysis, suggesting that OJ $-i$ may be a loan from Korean. We return to this point in our discussion of EMJ in 6.3.

${ }^{4}$ Antipassives are common in strictly ergative languages: transitive subjects are marked by absolutive case and objects by oblique case. It is widely claimed that the historical shift from ergative to accusative languages results from reanalysis of antipassives as accusative transitives (e.g. Bittner and Hale 1996).

${ }^{5}$ Miyagawa (1989, footnote 7) recognizes four counterexamples to the generalization that direct objects in adnominal clauses are uniformly marked with wo in OJ. Miyagawa suggests that the examples are noun-verb compounds. In fact, the number of bare $\mathrm{N}^{0}+$ verb examples in the Man'yôsh $\hat{u}$ is much larger, and the quantity and lexical variety of these examples indicate a productive process of noun incorporation rather than lexicalized compounds.

${ }^{6}$ Many different terms have been used to describe active alignment. Van Valin (1990) introduces the term split intransitivity; others include variations on Sapir's (1917) original active-stative, agent-patient (cf. Klimov 1977, Mithun 1991), fluid-S/split S (Dixon 1979, 1994). Klimov (1977) correlates a wide variety of lexical and syntactic traits with active alignment.

${ }^{7}$ Mithun (1991) identifies the semantic basis of the active marking of various West Hemisphere languages, both synchronically and diachronically.

8 There are a few examples in which specific but nonhuman nouns such as $p i$ 'the sun' or animals of special significance such as tadu 'crane' and siwa 'snipe' are marked with ga. These are almost certainly examples of personification, a prominent rhetorical device in the Man'yôshû.

${ }^{9}$ Stative verbs such as wori 'be at, sit' and unaccusative verbs such as $k u$ 'come' appear with $g a$ when the subject is a first or second person pronominal, which are ranked highest on the nominal hierarchy.
(i) a.
米豆良之伎 吉美我
伎麻佐婆 
medurasiki kimiga ki-mas-aba

(MY 18/4050)

charming lord Act come-Hon-if

'if my charming lord comes'

b. 和我乎礼婆宇良之保 美知 久

wa ga wor-eba ura sipo miti

$k u$

(MY 15/3707)

I Act be-when bay tide be.full comes

'When I am there the tide will be high in the bay.'

${ }^{10}$ Note that (19a) is an example from Eastern Old Japanese.

11 Approximately 120 occurrences of subject (w)a-ga are found in the Man'yôsh $\hat{u}$ (based on the Yoshimura's electronic text); all are immediately adjacent to the verb. (Data cited here include personal pronouns written with phonographs but not the freestanding ideograph 吾, which can be read with or without a case particle.)

${ }^{12}$ Sasaki (1996) cites 7 examples from the Man'yôshû in which he claims that ga appears with a predicate in the conclusive form. (We exclude examples involving the character 之, since this character can be read either as the case marker $g a$ /no or the focus adverbial si.) (21b) above is one of the examples cited by Sasaki; closer inspection of his data reveals that in 6 out of Sasaki's 7 examples, as in (21b), the subject is not in the conclusive to-clause, but in the higher clause whose predicate is in the adnominal form. The structure of these six clauses, like (21b), is $\left[\right.$ Subject-ga $\left.\mathrm{i}_{\mathrm{i}}\left[\mathrm{pro}_{\mathrm{i}} \ldots \mathrm{V}_{\text {conc }}\right] \mathrm{V}_{\mathrm{adn}}\right]$, where the embedded subject is a phonologically null pro coindexed with the $g a$-marked subject in the higher adnominal clause.

13 This contrasts with approaches that posit a category-fixing head $n$ that selects an acategorial root (Marantz 1997) or $v \mathrm{P}$ (Alexiadou 2001). Such an approach is not impossible in OJ, but the category-fixing head would have to select T.

${ }^{14}$ However in Turkish the locus of nominalization is higher than OJ: Kornfilt (2003) places it in the Agr or Finite head where subject agreement is spelled out above the Tense-AspectModal projections. OJ, like modern $\mathrm{J}$, has no overt agreement morphology in this position, nor is there any overt Finite or $\mathrm{C}$ morpheme above the TAM auxiliaries. Instead what we find are adnominal, etc. allomorphs of these auxiliaries. For this reason we interpret the adnominal and other nominalized forms as the spellout of [nominal] $\mathrm{T}$.

15 The parentheses on the totals for conclusive and imperative examples of $i$-indicate that all three of these examples are subject to alternative analyses, as discussed below.

16 Wrona (2006 ms.) cites the second clause of (27) miti no kuma i-tumor-u as a counterexample to the generalization that $i$ - appears only on active verbs, interpreting this 
clause as 'bends of the road pile up'. This interpretation is also followed by Kojima et al (1995) and Satake et al (2002). But Nakanishi (1978/2004) interprets personificational 'Mt. Miwa' as the subject of both clauses. Because this preserves the evident parallelism of the two clauses, we have followed Nakanishi's interpretation here.

17 To be precise, 40 of the 44 infinitive examples have human agentive pro subjects. Two have personificational subjects, shirakum(w)o mo 'white clouds too' (MY 317) and amakum(w)o mo 'sky-clouds too' (MY 319), both occurring with unergative $i$-YUKI ' $i+$ going'. Both NPs are marked with the subdued focus marker mo 'too/even' suggesting that they are external to the infinitive clause. Only two examples have possible clause-internal non-agentive subjects, but both of these (MY 2145 and 3409) are problematic of interpretation. MY 2145 is particularly instructive. Kojima et al (1995.3: 111) note that the infinitive clause in question sa-wosika no kowe i-tuki i-tuki 'the voice of the buck $i$-continuing, $i$-continuing' must be interpreted in context as an elliptical realis (izenkei) conditional: 'when pro hears the voice of the buck'.

18 Satake et al (2002.3: 205) also acknowledge this interpretation.

193 of the 5 counterexamples involve ne- 'sleep' with human subjects: conclusive (MY 2782) and two with imperative (MY 636,2629). Since sa-ne 'sa+sleeping' also occurs as a noun, these examples may be backformations. The remaining two counterexamples, conclusive MY 859 and 4156, both involve the collocation ayu sa-basiru 'the sweetfish sa-runs'.

${ }^{20}$ Sateré-Mawé (Tupian) has an active system marked by two series of personal prefixes on the verb (cf. Mithun 1991). Meira (2006) shows that in Mawé nonactive verbs are strikingly similar to (possessed) nouns: the same set of personal prefixes appears on nouns and nonactive verbs; these prefixes do not select active verbs.

${ }^{21}$ On both nouns and verbs $s a$ - (but not $i$-) triggers rendaku (realized in OJ as prenasalization) on the following voiceless obstruent. This suggests an etymological source of the shape *saN(V). *Sa may be related to the mesial pronouns sa 'thus', so 'that' and si 's/he it', while $* \mathrm{~N}(\mathrm{~V})$ appears related to genitive/inactive no.

${ }^{22}$ Commenting on (30b), Kojima et al (1995, vol. 3: 191) observe exactly the distinction we describe here between $i$-watar-and sa-watar-. They note that while $i$-watar-occurs only with human subjects, sa-watar- is restricted to nonhuman subjects. They fail to extend this distinction to other verbs, however.

${ }^{23}$ An apparent counterexample to this generalization is found in MY 804, where ga and prefixal $s a$ - appear to surface in the same clause:

(i) 遠等咩良何 佐那周伊多斗乎意斯比良伎 
wotomye-ra ga sa-nasu itado wo osipirak-i

maiden-Pl Act $s a$-sleep door Obj push open-Inf

'pushing open the door where the maidens sleep.'

Kojima et al (1972), however, interpret wotomyera ga 'maidens GA' as the genitive possessor of itado '(wooden) door', a metonymic expression for 'bedroom'; the entire NP then has the interpretation 'pushing open the maiden's (bedroom) door where they sleep' and the structure in (ii):

(ii) $\left[_{\mathrm{NP}}\right.$ wotomyera ga [[ pro sa-nasu ] itado]] wo osipirak-i maidens Gen sa-sleep door Obj pushopen-Cont

On this interpretation wotmyera ga is not the clausemate subject of sa-nasu 'sa-sleep'.

24 Miyamoto et al. (1999) report that Japanese children show a case marking pattern for subject NPs highly reminiscent of what we have described for OJ. They observe that children commonly omit nominative $g a$ for subjects of unaccusative verbs, while consistently using $g a$ for subjects of transitives and unergatives. They propose that the A-chain Deficit Hypothesis (ACDH) (Borer and Wexler 1987, 1992) accounts for why children treat unaccusatives differently from transitives and unergatives. From a learnability perspective, it may be worth pursuing a unified account for this parallel between the acquisition and syntactic change.

${ }^{25}$ We leave the precise landing site of no-marked unaccusative subjects in OJ for future research.

${ }^{26}$ It should also be noted that on the clitic analysis of pronoun $+g a$ (4.1, Yanagida 2007b), the bare object wa ga na 'my name' in (36) is not, strictly speaking, phrasal.

${ }^{27}$ See Hoji (1991) for a similar analysis of so-called Raising to Object constructions in modern Japanese.

${ }^{28}$ Kinsui (2001) also observes this generalization.

29 The example is:

(i) 夜麻能奈等 伊賓都夏等可母 佐用比賣何 Yamano na to ipitug-ye to kamo Saywopimye ga Mountain Gen name Comp say tell-Imp Comp Q Sayohime Act 許能野麻能閉仁必例遠 布利家牟 kono yama no pe ni pire wo puri-kyem-u (MY 5/872) this mountain top on scarf Obj wave-PPresum-Adn 'Might Sayohime have waved her scarf on the top of this mountain, (saying) "Pass it on! This mountain's name!" 
However this example is open to at least one other interpretation, where Sapywopime ga is taken as the possessive modifier of 'this mountain', i.e. 'On this, Sayohime's mountain, might she have waved her scarf (saying) ...'A A reviewer of Yanagida (2006) also cites MY $18 / 4036$ as a counterexample, but this is based on a misinterpretation of this example.

${ }^{30}$ It is widely held that inflected adjectives are a relatively late innovation in pre-OJ (Omodaka et al 1967: 41). It is easy to find OJ examples of uninflected adjectives directly modifying the noun, e.g. kanasi imwo 'dear beloved girl.'

${ }^{31}$ Ohno's analysis is generally accepted, but its weak point is that there is no attested noun of the form *aku. An alternative preserving the core of Ohno's insight would derive $a k u$ from the existential verb root $a$ - 'exist' plus the adjectival continuative $-k u$. It has long been pointed out that derivatives of $a$ - partake in "stative"-type inflections, e.g. conclusive $-i$ in $a r-i$ 'exists.' Nominals in - $(a) k u$ would then derive from V-ADNOM + exist-CONT, 'being V.'

${ }^{32}$ See Manning (1996) for the global hypothesis that certain types of ergativity, in the broad sense, have their diachronic origins in nominalizations. We are grateful to Dan Kaufman for pointing us in the direction of this and other research in the 'nominalist' tradition of studies on ergativity, including his own.

33 We provide only the segmented morphophonemic representation of Gildea's Panare data in (50), for clarity of presentation.

${ }^{34}$ Some linguists, such as Tokieda (1954), relate wo to the OJ sentence-final particle wo, which is claimed to be emphatic; Tokieda thus claims that the original function of object marking wo was emphatic. Whatever is meant by emphatic in this context, it cannot mean, for example, focus, since wo marked objects in OJ are typically definite and presupposed.

35 There is one counterexample in the Konkômyô Saishô Ôkyô where a nonpronominal subject takes $g a$ and the object takes wo, in (i).

(i) 我弟 捨身 (K 10-26:192)

waga wotofito ga mi wo tutete...

my Gen brother Agt oneself Acc sacrifice

'My brother sacrificed himself.'

The eventual reanalysis of $g a$ as a nominative particle in Tokyo and Kansai Japanese is a topic that far exceeds the scope of this paper. Yamada (2000) examines the increase in the frequency of $g a$ by comparing the original text of the Tale of Heike, which is believed to reflect the language of the fourteenth century, with the Jesuit romanized text of Heike, known as the Amakusa Heike, published in 1592. He observes that many of unmarked subjects in the Tale of Heike came to be marked by ga in Amakusa Heike. This may indicate that $g a$ 
reappeared as a nominative case in the late $16^{\text {th }}$ century. The matter is confounded by the association of $g a$ and no with pejorative and honorific functions, as reported by Jesuit grammarians in the early $17^{\text {th }}$ century. Interestingly, according Yamada's observation, $g a$ in this period is used on the subjects of unaccusative verbs and adjectives, but rarely on the subjects of a transitive/unergative verb. This contrasts directly with the distribution of $g a$ in the Man'yôshû.

${ }^{36}$ According to Koji (1988), there are a total of 1557 instances of object marking wo in the Manyôshû.

\section{Acknowledgements}

We wish to express our deep appreciation to Shigeru Miyagawa, Kunio Nishiyama, Alexander Vovin, and an anonymous JEAL reviewer for their comments. The authors are of course responsible for any errors. Work on this paper was supported by grants-in-aid for scientific research from the Japan Society for the Promotion of Science (JSPS) to Yanagida and a Japan Foundation grant to Whitman.

This paper is dedicated to the memory of S.-Y. Kuroda.

\section{Texts (Primary Sources)}

Kasuga, Masaji. 1969. Konkomyô Saishô Ôkyô Koten no Kokugogakuteki Kenkyû. Tokyo: Benseisha

Koji, Kazuteru. 1988. Man'yôshû Joshi no Kenkyu. Tokyo: Kasama Shoin.

Kojima, Noriyuki; Kinosita, Masatake; and Tôno, Haruyuki. 1995. Man’yôshû (1-4), Nihon Koten Bungaku Zenshî. Tokyo: Shogakkan.

Nakanishi, Susumu. 1978-1983. Man'yôshû. Tokyo: Kôdansha Bunko, (reprinted in 1978-2005).

Satake, Asahiro, Kudô, Rikio, Ohtani, Masao and Yamazaki Yoshiyuki. 2002. Man'yôshû Shin Nihon Koten Bungaku Taikei (1-4). Tokyo: Iwanami.

\section{Electronic Texts}

Japanese Text Initiative Electronic Text Center, University of Virginia Library (http://etext.lib.virginia.edu/japanese/jti.texts.euc.html)

National Institute of Japanese Literature (http://www.nijl.ac.jp/contents/d_library/index.html) 
Yoshimura, Makoto（http://yoshi01.kokugo.edu.yamaguchi-u.ac.jp/manyou/manyou.html）

\section{References}

Aldridge, Edith. 2004. Ergativity and word order in Austronesian languages. Doctoral dissertation, Cornell University.

Alexiadou, Artemis. 2001. Functional structure in nominals: Nominalization and ergativity. Amsterdam: John Benjamins.

Alexiadou, Artemis and Elena Anagnostopoulou. 2008. Structuring participles. Proceedings of WCCFL 26.

Allen, Nicholas J. 1975. Sketch of Thulung grammar. Cornell University East Asia Papers 6, Cornell University, Ithaca, NY.

Baker, Mark, C. 1988. Incorporation. Chicago: The University of Chicago Press.

Bittner, Maria and Ken Hale. 1996. The structural determination of case and agreement. Linguistic Inquiry 27:1-68.

Bricker, Victoria. 1981. The source of the ergative split in Yukatek Maya. Journal of Mayan Linguistics 2(2): 83-127.

Borer, Hagit and Ken Wexler. 1987. The maturation of syntax. In Parameter setting, ed. by Thomas Roeper and Edwin Williams, 123-172. Dordrecht: Reidel.

Chomksy, Noam. 2001. Minimalist inquiries: the framework. In Step by step: Essays on minimalist syntax in honor of Howard Lasnik, ed. by Roger Martin, David Michaels and Juan Uriagereka, 89-156. Cambridge: MIT Press.

Comrie, Bernard. 1978. Ergativity. In Syntactic typology, ed. by Winfred Lehmann, 329-394. Austin: University of Texas Press.

Dahlstrom, Amy. 1983. Agent-patient languages and split case marking systems. In Proceedings of the 9th Annual Meeting of the Berkeley Linguistic Society, BLS 9, $37-46$.

Diesing, Molly. 1992. Indefinites. Cambridge, MA. : MIT Press.

Dixon, R.M.W. 1972. The Dyirbal language of North Queensland. Cambridge: Cambridge University Press.

Dixon, R.M.W. 1979. Ergativity. Language 55: 59-138.

Dixon, R.M.W. 1994. Ergativity. Cambridge: Cambridge University Press.

Embick, David. 2004. On the structure of resultative participles in English. Linguistic Inquiry 35.3: 355-392.

Frellesvig, Bjarke and John Whitman. 2008. Proto-Japanese. Amsterdam: John Benjamins. Gildea, Spike. 1998. On reconstructing grammar. Oxford: Oxford University Press. 
Gildea, Spike. 2000. On the genesis of the verb phrase in Cariban languages. In

Reconstructing grammar: Comparative linguistics and grammaticalization, ed. by Spike Gildea, 65-106. Amsterdam: John Benjamins.

Harada, Shin-Ichi.1971. Ga-no conversion and ideolectal variations in Japanese. Gengo kenkyû 60: 25-38.

Hendriks, Peter. 1998. Kakari particles and the merger of the predicative and attributive forms in the Japanese verbal system. Japanese/Korean Linguistics 7: 197-210.

Hoji, Hajime. 1991. Raising-to-object, ECM, and the major object in Japanese. Paper presented at the Japanese Syntax Workshop. University of Rochester.

Johns, Alana. 1992. Deriving ergativity. Linguistic Inquiry 23.1: 57-87.

Kaufman, Daniel. 2007. The nominalist hypothesis in Austronesian. Paper given at ZAS Berlin, August 142007.

Kinsui, Satoshi. 1993. Kotengo no wo ni tsuite [On the particle wo in premodern Japanese]. In Nihongo no Kaku o Megutte [Perspectives on Case in Japanese], ed. by Nitta Yoshio, 191-224. Tokyo: Kurosio Publishers.

Kinsui, Satoshi. 2001. Handout, Osaka University.

Klimov, Georgij A. 1974. On the character of languages of active typology. Linguistics 131: 11-25.

Klimov, Georgij A. 1977. Tipologija jazykov aktivnogo stroja [Typology of languages of the active type]. Moscow: Nauka.

Konoshima, Tadatoshi. 1962. Chûkogo ni okeru yôgen rentaikei no yôhô [The use of the participial adjective in medieval Japanese]. Kokugogaku 48: 102-7.

Kornfilt, Jaklin. 2003. Subject case in Turkish nominalized clauses. In Syntactic structures and morphological information, ed. by Uwe Junghanns and Luka Szusich, 130-214. Berlin: Mouton de Gruyter.

Kuginuki, Tôru. 1996. Kodai Nihongo no keitai henka [Morphological change in earlier Japanese]. Osaka: Izumi Shoin.

Kuroda, Sige-Yuki. 1988. Whether we agree or not: a comparative grammar of English and Japanese. Linguisticae Investigationes. 12: 2-44.

Kuroda, Shige-Yuki. 2007. On the syntax of Old Japanese. In Current issues in the history and structure of Japanese, Bjarke Frellesvig, J.C. Smith and Masayoshi Shibatani, 263-318. Tokyo: Kurosio.

Lahaussois, Aimee. 2003. Ergativity in Thulung Rai: a shift in the position of pronominal split. Language variation: Papers on variation and change in the Sinosphere and in the Indosphere in honour of James A. Matisoff. Pacific Linguistics, 101-112. 
Legate, Julie. 2008. Morphological and abstract case. Linguistic Inquiry 39.1: 55-101.

Lightfoot, David. 1991. How to set parameters: Arguments from language change. Cambridge, MA.: MIT Press.

Mahajan, Anoop Kumar. 1990. The A/A' distinction and movement theory, MIT

Dissertation, Cambridge, MA.

Manning, Christopher D. 1996. Ergativity: Argument structure and grammatical relations. Stanford, CA: CSLI Publications.

Marantz, Alec. 1997. No escape from syntax: Don't try morphological analysis in the privacy of your own lexicon. In University of Pennsylvania Working Papers in Linguistics, Vol. 4.2, 201-225.

Meira Sergio. 2006. Stative verbs vs. nouns in Sateré-Mawé and the Tupian family. In What's in a verb: Studies in the verbal morphology of the languages of the Americas, Lot Occasional Series, 189-214, ed. by Graz'yna J. Rowicka and Eithne B. Carlin. Netherlands Graduate School of Linguistics, Netherlands.

Mithun, Marianne. 1991. Active/agentive case marking and its motivations. Language 67.3: $510-546$.

Miyagawa, Shigeru. 1989. Structure and case marking in Japanese. Syntax and semantics 22. New York: Academic Press.

Miyagawa, Shigeru. 1993. Case checking and the Minimal Link Condition. In Case and agreement II, MIT Working Papers in Linguistics 19: 213-254.

Miyagawa, Shigeru and Fusae Ekida. 2003. Historical development of the accusative case marking in Japanese as seen in classical literary texts. Journal of Japanese Linguistics 19: 1-95.

Miyamoto, Edson T., Kenneth Wexler, Takako Aikawa, and Shigeru Miyagawa. 1999. Case-dropping and unaccusatives in Japanese acquisition. BUCLD 23: 443-452.

Motohashi, Tatsushi. 1989. Case theory and the history of the Japanese language, $\mathrm{PhD}$ Dissertation, Universityof Arizona.

Nomura, Takashi. 1993. Jôdaigo no no to ga ni tsuite [On the particles no and ga in Old Japanese]. Kokugo Kokubun 62: 1-17.

Nomura, Takashi. 1996. Ga-shûsikei e [The Ga-Conclusive form]. Kokugo kokubun 65: 524-541.

Ohno, Susumu. 1953. Nihongo no dôshi no katsuyôkei no kigen ni tuite [On the origin of the Japanese verb conjugations]. Kokugo to kokubungaku 350: 47-56.

Ohno, Susumu. 1955. Man'yô jidai no on'in [The phonology of the Man'yô period]. Man'yôshû taisei 6: 287-332. 
Ohno, Susumu. 1993. Kakarimusubi no kenkyû [Research on kakarimusubi]. Tokyo: Iwanami Shoten.

Omodaka Histaka et. al. 1967. Jidaibetsu kokugo daijiten, jôdai-hen [A dictionary of Japanese by period, Old Japanese edition]. Tokyo: Sanseido.

Roberts Ian, and Anna Roussou. 2003. Syntactic change: A minimalist approach to grammaticalization. Cambridge: Cambridge University Press.

Sakakura, Atsuyoshi. 1966. Gokôsei no kenkyû [Research on Word Formation]. Tokyo: Kadokawa shoten.

Sasaki, Takashi. 1996. Jôdaigo no kôbun to hyôki [The sentence structure and orthography of Old Japanese. Tokyo: Hituzi Shobô.

Sapir, Edward. 1911. The problem of noun incorporation in American languages. American Anthropologist 13: 250-282.

Sapir, Edward. 1917. Review of C.C Uhlenbeck: Het Passieve Karakter... In The collected works of Edward Sapir V (1990), ed. by W. Bright, 69-74. Berlin and New York: Mouton de Gruyter.

Silverstein, Michael. 1976. Hierarchy of features and ergativity. In Grammatical categories in Australian languages, ed. by R.M.W. Dixon, 112-171. Canberra: Australian Institute of Aborignal Studies.

Spencer, Andrew. 1999. Chukchee homepage. $<$ http://privatewww.essex.ac.uk/ spena/Chukchee/CHUKCHEE_HOMEPAGE.ht $\mathrm{ml}>$

Starosta, Stanley, Andrew Pawley, and Lawrence Reid. 1982. The evolution of focus in Austronesian. In Papers from the Third International Conference on Austronesian Linguistics, Vol. 2: Tracking the travelers, Pacific Linguistics C-75, 145-170, ed. by S.A. Wurm and L. Carrington.

Tokieda, Motoki. 1954. Nihon bunpô kôgo-hen [Japanese grammar, colloquial language edition]. Tokyo: Iwanami Shoten.

Van Valin, Robert D. 1990. Semantic parameters of split intransitivity. Language 66.2: 221-260.

Vovin, Alexander. 1997. On the syntactic typology of Old Japanese. Journal of East Asian Linguistics 6: 273-290.

Vovin, Alexander. 2005. A descriptive and compartive grammar of Western Old Japanese. Vol. 1. Folkestone: Global Oriental.

Washio, Ryuichi. 2004. Auxiliary selection in the East. Journal of East Asian Linguistics 13: 197-256. 
Watanabe, Akira. 2002. The loss of overt wh-Movement in Old Japanese. In Syntactic effects of morphological change, ed. by David W. Lightfoot, 179-195. Oxford: Oxford University Press.

Whitman, John. 1997. Kakarimusubi from a Comparative Perspective. In Japanese/Korean Linguistics 6, ed. by Ho-min Sohn and John Haig, 161-178. Stanford: CSLI.

Whitman, John. 2004. The reconstruction of the rentaikei and origins of the izenkei. Paper given at the Oxford Kobe Symposium on the History of Japanese.

Whitman, John. 2005. Preverbal elements in Korean and Japanese. In The Oxford handbook of comparative syntax. ed. by Guglielmo Cinque and Richard Kayne, 880-902. Oxford: Oxford University Press.

Wichmann, Søren. 2008. The study of semantic alignment: Retrospect and state of the art. In The typology of semantic alignment. In Wichmann and Donohue 2008, 3-23. Cambridge: Cambridge University Press.

Wichmann, Søren and Mark Donohue. 2008. The Typology of semantic alignment. Cambridge: Cambridge University Press.

Woolford, Ellen. 1997. Four-way Case systems: Ergative, nominative, objective, and accusative. Natural Language and Linguistic Theory 15: 181-227.

Wrona, Janick. 2006. Why Old Japanese was not an ergative language. Kyoto University ms.

Wrona, Janick. 2008. A study of Old Japanese syntax: Synchronic and diachronic aspects of the complement system. London: Global Oriental.

Yamada, Masahiro. 2000. Shugo hyôji ga no seiryoku kakudai no yôso [The expansion of the use of the subject denotor ga: A comparison between the original Text of the Tale of Heike and Amakusaban Heike]. Kokugogaku 51-1: 1-14.

Yanagida, Yuko. 2005. Ergativity and bare nominals in Early Old Japanese. Paper presented at Workshop on Theoretical East Asian Linguistics, Harvard University, Cambridge, MA.

Yanagida, Yuko. 2006. Word order and clause structure in Early Old Japanese. Journal of East Asian Linguistics 15: 37-68.

Yanagida, Yuko. 2007a. Miyagawa's (1989) exceptions: An ergative analysis. MIT Working Papers in Linguistics 55: 265-276.

Yanagida, Yuko. 2007b. Jôdaigo no nôkakusei ni tsuite [On ergativity in Old Japanese]. In Nihongo no shubun genshô [Main clause phenomena in Japanese], ed. by Nobuko Hasegawa, 147-188. Tokyo: Hituzi Shobo. 